\title{
Dicarboxylate Transporters of Azospirillum brasilense Sp7 Play an Important Role in the Colonization of Finger Millet (Eleusine coracana) Roots
}

\author{
Vijay Shankar Singh, ${ }^{1}$ Prajna Tripathi, ${ }^{1}$ Parul Pandey, ${ }^{1}$ Durgesh Narain Singh, ${ }^{2}$ Basant Kumar Dubey, ${ }^{2}$ \\ Chhaya Singh, ${ }^{1}$ Surendra Pratap Singh,${ }^{3}$ Rachana Pandey, ${ }^{4}$ and Anil Kumar Tripathi ${ }^{1,+}$ \\ ${ }^{1}$ School of Biotechnology, Institute of Science, Banaras Hindu University, Varanasi-221005, India \\ ${ }^{2}$ Laboratory of Synthetic Biology, Division of Biotechnology, CSIR-Central Institute of Medicinal and Aromatic Plants, Lucknow- \\ 226015, India \\ ${ }^{3}$ Department of Botany, Dayanand Anglo-Vedic (PG) College (Affiliated to CSJM University, Kanpur), Civil Lines, Kanpur- \\ 208001, India \\ ${ }^{4}$ Dr D Y Patil Biotechnology and Bioinformatics Institute, Dr D. Y. Patil Vidyapeeth Pune-411033, India
}

Accepted 25 January 2019.

\begin{abstract}
Azospirillum brasilense is a plant growth-promoting bacterium that colonizes the roots of a large number of plants, including $\mathrm{C3}$ and $\mathrm{C} 4$ grasses. Malate has been used as a preferred source of carbon for the enrichment and isolation Azospirillum spp., but the genes involved in their transport and utilization are not yet characterized. In this study, we investigated the role of the two types of dicarboxylate transporters (DctP and DctA) of $A$. brasilense in their ability to colonize and promote growth of the roots of a $\mathrm{C4}$ grass. We found that DetP protein was distinctly upregulated in A. brasilense grown with malate as sole carbon source. Inactivation of $\operatorname{dct} P$ in $A$. brasilense led to a drastic reduction in its ability to grow on dicarboxylates and form cell aggregates. Inactivation of $\operatorname{dct} A$, however, showed a marginal reduction in growth and flocculation. The growth and nitrogen fixation of a dctP and $d c t A$ double mutant of $A$. brasilense were severely compromised. We have shown here that DetPQM and DetA transporters play a major and a minor role in the transport of $\mathrm{C}_{4}$-dicarboxylates in $A$. brasilense, respectively. Studies on inoculation of the seedlings of a $\mathrm{C} 4$ grass, Eleusine corcana, with $A$. brasilense and its dicarboxylate transport mutants revealed that dicarboxylate transporters are required by $A$. brasilense for an efficient colonization of plant roots and their growth.
\end{abstract}

Keywords: $\mathrm{C}_{4}$-dicarboxylate, cell aggregation, DctP, DctA, nitrogen fixation, TRAP

${ }^{\dagger}$ Corresponding author: A. K. Tripathi; tripathianil@rediffmail.com

Funding: V. S. Singh was supported by a JRF/SRF fellowship to the University Grant Commission (UGC), New Delhi. P. Tripathi and P. Pandey were supported financially by UGC and Indian Council of Agricultural Research (ICAR), respectively. C. Singh, D. N. Singh and R. Pandey also acknowledge financial support from the Indian Council of Medical Research (ICMR), ICAR and Department of Biotechnology (DBT), respectively.

*The $\boldsymbol{e}$-Xtra logo stands for "electronic extra" and indicates that eight supplementary figures are published online.

The author(s) declare no conflict of interest.

๑) 2019 The American Phytopathological Society
Bacteria of the genus Azospirillum are nitrogen-fixing and plant growth promoting rhizobacteria, which colonize the roots of a variety of plants including nonleguminous grasses and cereals (Okon et al. 1976, 1980; Pereg et al. 2016). The plant growth-promoting effect of Azospirillum spp. is observed due to its ability to produce phytohormones, siderophores, and to fix atmospheric nitrogen (Steenhoudt and Vanderleyden 2000). Azospirilla efficiently colonize and proliferate in the rhizosphere due to their preference for dicarboxylates as carbon source (Alexandre et al. 2000; Christiansen-Weniger 1992 ; Steenhoudt and Vanderleyden 2000). Under conditions of high carbon and low nitrogen, they form cysts embedded in a fibrillar matrix to form flocs or aggregates that help them in coping with stress conditions and root colonization (Burdman et al. 1998; Pereg Gerk et al. 1998; Sadasivan and Neyra 1985). They also show maximum rates of nitrogen fixation with dicarboxylates such as malic acid and succinic acid as carbon source (Martinez-Drets et al. 1984). This is why malic acid is routinely incorporated as a carbon source in semisolid media used for the enrichment and culture of Azospirillum spp. (Albrecht and Okon 1980; Neyra and Döbereiner 1977; Vanstockem et al. 1987). Since A. brasilense utilizes $\mathrm{C}_{4}$-dicarboxylates in preference to carbohydrates (Goebel and Krieg 1984), this phenomenon was described as 'reverse diauxie' or 'reverse catabolite repression' (Mukherjee and Ghosh 1987).

Transport of $\mathrm{C}_{4}$-dicarboxylates, such as malate, succinate, and fumarate (tricarboxylic acid cycle intermediates) in bacteria occurs via different transporters (Janausch el al. 2002). While the Dcu-type transporter family facilitates the uptake of $\mathrm{C}_{4}$-dicarboxylates under anaerobic conditions, the most common transporters of $\mathrm{C}_{4}$-dicarboxylates under aerobic conditions include members of DASS (divalent anion sodium symporter), DAACS (dicarboxylate amino acid-cation symporter), TRAP (tripartite ATP-independent periplasmic), and CitMHS transporter families (Youn et al. 2009). DctA represents the DAACS family of transporters, which is involved in the uptake of $\mathrm{C}_{4}$ dicarboxylates in bacteria including Escherichia coli, Bacillus subtilis, or Rhizobium leguminosarum (Asai et al. 2000; Davies et al. 1999; Reid and Poole 1998). The DctABD system consists of three clustered genes, $d c t A$ encoding a $\mathrm{C}_{4}$-dicarboxylates transporter protein and two divergently oriented genes, $d c t B$ and $d c t D$, encode a two-component regulatory system involved in the sensing of $\mathrm{C}_{4}$-dicarboxylates and regulating the expression of $d c t A$ (Engelke et al. 1989; Ronson et al. 1984; Yurgel and Kahn 
2004). Mutation in any of the three $d c t$ genes causes loss of the ability to transport $\mathrm{C}_{4}$-dicarboxylates (Engelke et al. 1987; Finan et al. 1988) in free-living rhizobia. The dctA mutant of Rhizobium also fails to fix nitrogen under symbiotic condition on plants (Reid and Poole 1998).

TRAP transporter was first identified and characterized as a $\mathrm{C}_{4^{-}}$ dicarboxylate transporter in the purple photosynthetic bacterium Rhodobacter capsulatus (Forward et al. 1997; Shaw and Kelley 1991). It is encoded by a tricistronic operon (dctPQM), in which $d c t P$ encodes a high-affinity $\mathrm{C}_{4}$-dicarboxylate binding periplasmic protein and $d c t Q$ and $d c t M$ encode integral membrane proteins (Forward et al. 1997). A dctSR operon, organized divergently to the $\operatorname{dct} P Q M$ operon, encodes a two-component system that regulates the expression of the $\operatorname{dct} P Q M$ operon (Hamblin et al. 1993).

In spite of several lines of evidences suggesting the importance of $\mathrm{C}_{4}$-dicarboxylates for the growth, nitrogen-fixation, and rhizosphere colonization by Azospirillum spp., the genes involved in $\mathrm{C}_{4}$-dicarboxylate utilization were not characterized. Although the role of dicarboxylate transport in Rhizobium-legume symbiosis is well-established (Ronson et al. 1981), the role of dicarboxylates and their transporters in the colonization and proliferation of plant roots by Azospirillum spp. has not yet been reported. In this study, we have investigated the role of two $\mathrm{C}_{4}$-dicarboxylate transporters (DctP and DctA) of A. brasilense Sp7 in its ability to grow and fix nitrogen on dicarboxyates as sole carbon source. We have also shown here that the dicarboxylate transporters of A. brasilense Sp7 play important role in the colonization and proliferation of the roots of finger millet (Eleusine coracana), a $\mathrm{C}_{4}$ grass.

\section{RESULTS}

\section{Identification of a $\mathbf{C}_{\mathbf{4}}$-dicarboxylate-induced protein in A. brasilense Sp7.}

A comparison of growth of A. brasilense Sp7 in minimal medium (MM) with malate, succinate, fumarate or fructose as sole source of carbon indicated that malate, succinate and fumarate were utilized much more efficiently than fructose (Fig. 1A). The growth curves of $A$. brasilense Sp7 obtained with 20$\mathrm{mM}$ concentrations of the above carbon sources showed a similar pattern of growth, except that the growth with $40 \mathrm{mM}$ reached 1.6 at an optical density at $600 \mathrm{~nm}\left(\mathrm{OD}_{600}\right)$, while the $\mathrm{OD}_{600}$ of cultures grown with $20 \mathrm{mM}$ reached 1.2 (Supplementary Fig. S2). In the case of $\mathrm{C}_{4}$-dicarboxylates, $A$. brasilense $\mathrm{Sp} 7$ grew exponentially from 4 to $16 \mathrm{~h}$, after which a stationary phase started. A sodium dodecyl sulfate-polyacrylamide gel electrophoresis (SDSPAGE) protein profile of $A$. brasilense cultures, grown with malate, succinate, or fumarate as sole carbon source for $20 \mathrm{~h}$, showed a protein of $37 \mathrm{kDa}$ (Fig. 1B), which was strongly upregulated in malate-grown culture but was absent in fructose-grown cultures. This protein was also upregulated in succinate- or fumarate-grown cultures, but the intensity of the band was considerably weaker than that seen in malate-grown culture. This upregulated protein was eluted and trypsin-digested and was submitted for peptide mass fingerprinting by matrix-assisted laser desorption-ionization (MALDI) tandem time of flight assay. The peptide sequences obtained from the 37-kDa protein matched with the DctP (AZOBR_140140) protein of A. brasilense (Supplementary Fig. S1). This protein is a member of the tripartite TRAP transporter, which consists of three proteins, DctP, DctQ, and DctM. The gene encoding DctP was the first gene of the $d c t P Q M$ operon (Fig. 2A) that was organized divergently to the genes encoding DctS (encoding a sensor) and DctR (encoding a regulator), which are known to regulate the expression of $d c t P Q M$ operon in R. capsulatus (Forward et al. 1997).

Although DctP (AZOBR_140140) was the most prominently upregulated band in the total proteins of $A$. brasilense grown with malate as carbon source, proteins of the predicted molecular weights of DctQ (25 kDa) and DctM (47.52 kDa) could not be seen by SDS-PAGE. To understand this anomaly, we carried out a reverse transcription-polymerase chain reaction (RT-PCR) from the total RNA isolated from A. brasilense Sp7 grown with malate as carbon source (Fig. 2B). The RT-PCR results showed that $\operatorname{dctP} Q M$ was cotranscribed as a single transcript in A. brasilense Sp7. To see if the intergenic region between $\operatorname{dct} P$ and $d c t Q M$ contains a potential terminator, we carried out an in silico analysis to search for a hairpin or steploop structure. While open reading frames of DctQ and DctM overlap by 3 nucleotides (nt), the intergenic region of $122 \mathrm{nt}$ between $\operatorname{dct} P$ and $\operatorname{dct} Q M$ harbored a potential hairpin structure (Fig. 2A), providing an explanation for a relatively lower level of expression of $d c t Q M$. It is also possible that DctP might be relatively more stable than DctQ and DctM.

\section{Phylogenetic and structural features of DctP protein from $A$. brasilense $\mathrm{Sp7}$.}

The DctP (AZOBR_140140) protein showed a maximum of $73 \%$ identity with the DctP (RCAP_rcc03024) of $R$. capsulatus and $45 \%$ identity with the DctP of Pseudomonas aeruginosa and Shewanella oneidensis (Fig. 3A). When we searched the genome of A. brasilense for DctP homologs, we found 14 paralogs of DctP, of which 12 were located on plasmids while two were located on the chromosome. Of the 14 DctP paralogs, 11 were part of complete $d c t P Q M$ operons (Supplementary Fig. S3), while the remaining three were not organized as an operon and were randomly distributed in the genome. The genes encoding DctS and DctR regulators, however, were found in the vicinity of the gene encoding DctP (AZOBR_140140). A phylogenetic tree of the 14 DctP paralogs of A. brasilense along with the DctP orthologs that have been characterized for their substrates showed that only AZOBR_140140 clustered with the known dicarboxylate transporters (Fig. 3A). The other DctP paralogs of $A$. brasilense showed only 27 to $45 \%$ identities with the DctP of $R$. capsulatus. They clustered with DctP orthologs that are known to transport substrates other than dicarboxylates.

For analyzing the affinity of DctP paralogs other than AZOBR 140140 toward dicarboxylates, we attempted to identify the presence of conserved residues involved in dicarboxylate binding. The crystal structure of DctP protein of Shewanella oneidensis (Protein Data Bank [PDB] ID 4MX6) bound to L-malate and DctP protein of P. aeruginosa (PDB ID 4NF0) bound to succinate (Vetting et al. 2015) indicated that Val-36 and 37, Lys-42 and 95, Arg-171, Gly173, Phe-195, Asn-211 and 215, and Tyr-238) were involved in the binding of L-malate and succinate in the pocket of the active site and were present at specific positions in both the structures (Fig. 3B). Alignment of DctP proteins from $R$. capsulatus, A brasilense, $P$. aeruginosa, and Shewanella oneidensis showed that amino acid residues responsible for the binding of L-malate and succinate were also conserved and were present at the same positions in the DctP protein (AZOBR_140140) of A. brasilense and $R$. capsulatus (Supplementary Figs. S4 and S5). In the remaining 13 DctP paralogs of $A$. brasilense, however, the residues involved in the binding of dicarboxylates were not fully conserved. Structural superimposition of the crystal structures 4MX6 and 4NF0 with the modeled structures of DctP from $R$. capsulatus and A. brasilense showed structural similarity (RMSD $<0.13 \mathrm{~nm}$ ) between each other, with identical pockets of the active site formed by the sequence motif VVX5KX59KX74/75RXQ/MX20F/YX16NX3NX22, which is responsible for interacting with $\mathrm{C}_{4}$-dicarboxylates (Fig. 3B). Docking of malate, succinate, and fumarate on DctP (AZOBR 140140) protein showed that the free energy change with malate was slightly more negative than that for succinate and fumarate (Supplementary Fig. S6), indicating that malate fits better in the active site pocket of DctP protein than succinate and fumarate. 
Effect of $\mathrm{C}_{\mathbf{4}}$-dicarboxylates on the expression of DctP protein.

To ascertain the inducibility of DctP expression by malate, a $d c t P: l a c Z$ fusion was constructed. The effect of malate, succinate, and fructose on the expression of $d c t P: l a c Z$ fusion yielded maximum $\beta$-galactosidase activity with malate and minimum activity with fructose (Fig. 1C). The $d c t P$ promoter activity with succinate was considerably higher than that on fructose but almost $45 \%$ of that shown by malate at $16 \mathrm{~h}$.

\section{Effect of inactivation of $\mathrm{dctP}$ gene}

on the growth of $A$. brasilense $\mathrm{Sp7}$.

The $\operatorname{dct} P$ gene of $A$. brasilense $\mathrm{Sp} 7$ was inactivated in vitro by inserting a kanamycin resistance $\left(\mathrm{Km}^{\mathrm{r}}\right)$ gene cassette in a cloned $\operatorname{dct} P$ gene (Supplementary Fig. S7A), which was placed in the A. brasilense $\mathrm{Sp} 7$ genome by allele replacement via homologous recombination. The exconjugants of $A$. brasilense showing resistance to $\mathrm{Km}$ were further analyzed by PCR amplification of the $\mathrm{Km}^{\mathrm{r}}$ gene from the genomic DNA of the mutant (designated as $d c t P:: \mathrm{km}$ ). Since $d c t P$ is the first gene of the $\operatorname{dct} P Q M$ operon, insertional inactivation of $d c t P$ is expected to have a polar effect on the expression of $d c t Q M$. The SDSPAGE profile of A. brasilense and its $\operatorname{dct} P:: \mathrm{km}$ mutant grown with malate as sole carbon source showed the presence of the $37-\mathrm{kDa}$ protein band in $A$. brasilense and its absence in the $\operatorname{dctP}:: k m$ mutant (Fig. 4B).

In comparison with $A$. brasilense $\mathrm{Sp} 7$, growth of the $d c t P:: k m$ mutant with malate as sole carbon source was drastically reduced (Fig. 4A). While A. brasilense entered into stationary phase at $20 \mathrm{~h}$, the $\operatorname{dct} P:: \mathrm{km}$ mutant entered stationary phase at
A
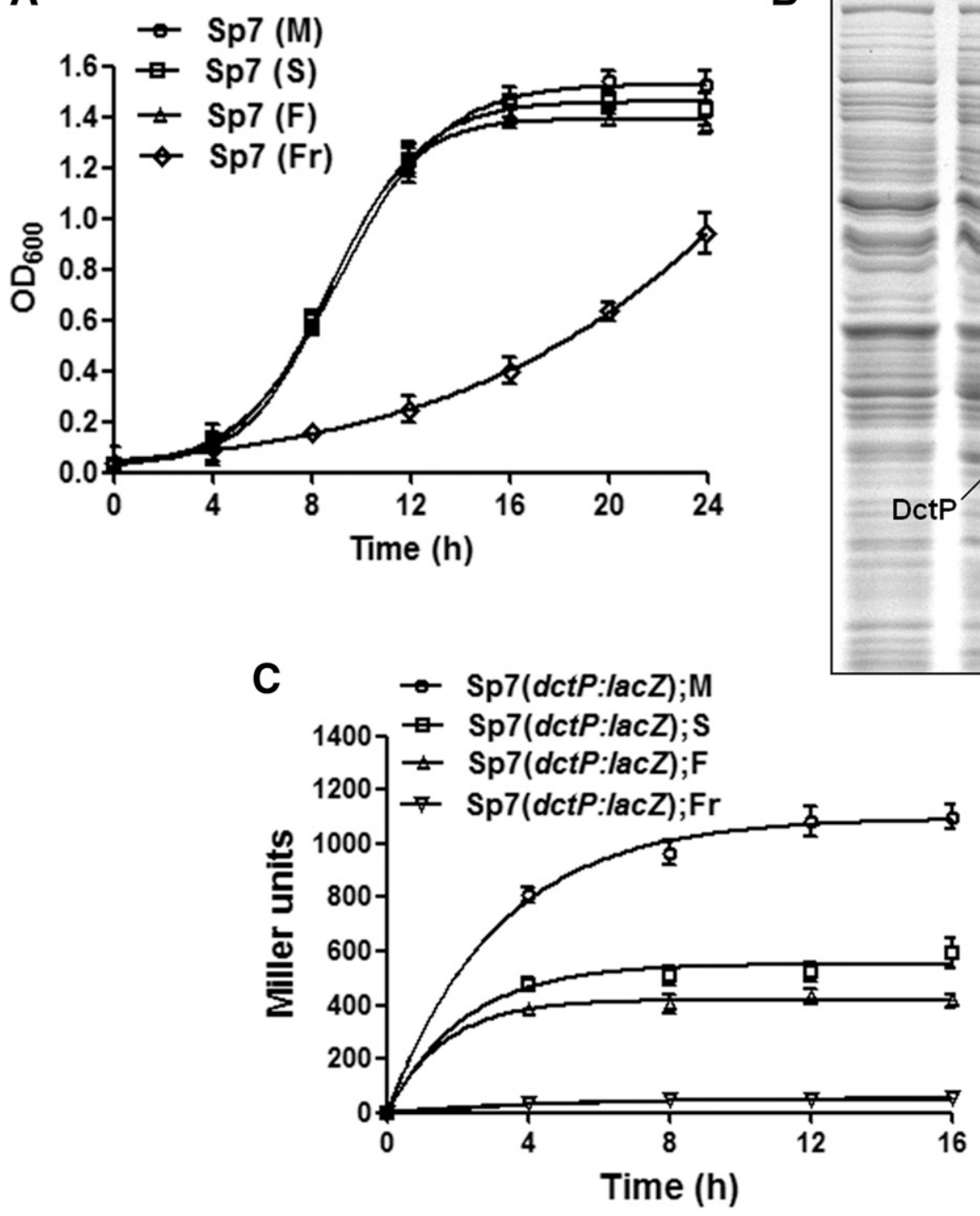

B

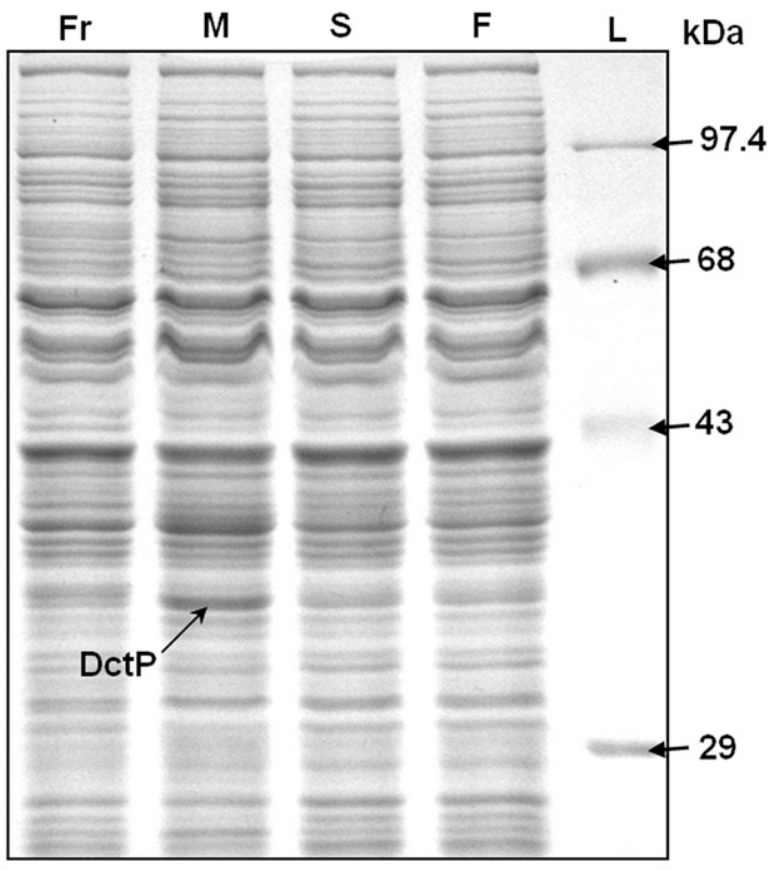

Fig. 1. A, Growth curves of Azospirillum brasilense Sp7 in minimal medium (MM) containing malate, succinate, fumarate, or fructose (each 40 mM) as sole source of carbon. Each point of the curve shows the mean of three replicates obtained from three independent experiments. Error bars show standard deviation (SD) at each point. $\mathrm{M}=$ malate, $\mathrm{S}=$ succinate, $\mathrm{F}=$ fumarate, Fr = fructose. B, Electropherogram (12\% sodium dodecyl sulfate-polyacrylamide gel electrophoresis) of the total proteins from A. brasilense $\mathrm{Sp7}$, grown in MM supplemented with different $\mathrm{C}_{4}$-dicarboxylates as sole carbon source, showing distinct upregulation of the DctP (AZOBR_140140) protein in lane M. This protein is also present in lanes S and F but absent in lane Fr. Every lane of the gel was loaded with $20 \mu \mathrm{g}$ of total proteins. Lane L shows protein molecular weight marker (Banglore genei). C, Effect of malate (M), succinate (S), fumarate (F) and fructose (Fr) on the expression of $d c t P$ :lacZ fusion in A. brasilense Sp7 grown in MM. The mean of triplicates in three independent experiments were calculated and are indicated with error bars in the form of SD. Data $(n=3)$ were analyzed using SPSS 17 software, and analysis of variance followed by Duncan's multiple comparison test was used to analyze significance between more than two treatments. Differences between means were compared and found significant at $P<0.05$. 
$12 \mathrm{~h}$. Complementation of the $d c t P:: k m$ mutant with a plasmid overexpressing the $\operatorname{dct} P Q M$ operon (pDCTPOVSS) led to restoration of the growth of the mutant almost to that of $A$. brasilense (Fig. 4A). Our attempt to complement with $d c t P$ alone did not restore the growth of the mutant.

\section{Effect of inactivation of $\boldsymbol{d c t A}$ gene} on the growth of $A$. brasilense Sp7.

Since inactivation of $d c t P$ in $A$. brasilense did not result in a complete loss of growth in media containing malate as carbon source, it was evident that $A$. brasilense uses more than one transporter to utilize $\mathrm{C}_{4}$-dicarboxylates for its growth. In light of this, we investigated the role of another dicarboxylate transporter, DctA in A. brasilense (Fig. 5A), which was homologous (62\% identity and $79 \%$ similarity) to a well-characterized DctA (PA1183) transporter of $P$. aeruginosa PAO1(Supplementary
Fig. S8). The dctA (AZOBR_p1140111) gene was inactivated by inserting a gentamycin resistance $\left(\mathrm{Gm}^{\mathrm{r}}\right)$ gene cassette and placing it back in the $A$. brasilense genome by allele replacement. A plasmid overexpressing the $d c t A$ gene was also constructed to learn if it could complement the ability of the $d c t A:: g m$ mutant to grow on malate (Fig. 5B). The growth of the $d c t A:: g m$ mutant on malate as sole carbon source was slower than that of $A$. brasilense $\mathrm{Sp} 7$ but was not as drastically affected as seen in the case of the dctP::km mutant (Fig. 5B).

\section{Effect of inactivation of $\operatorname{dctP}$ and $\operatorname{dctA}$ on the growth of $A$. brasilense Sp7.}

The growth of the $\operatorname{dct} A:: g m$ and $\operatorname{dctP}:: \mathrm{km}$ mutants and the $d c t A:: g m$ dctA::gm double mutant was compared with that of A. brasilense in $\mathrm{MM}$ with malate as sole carbon source. Figure 6 shows that the growth of the double mutant was

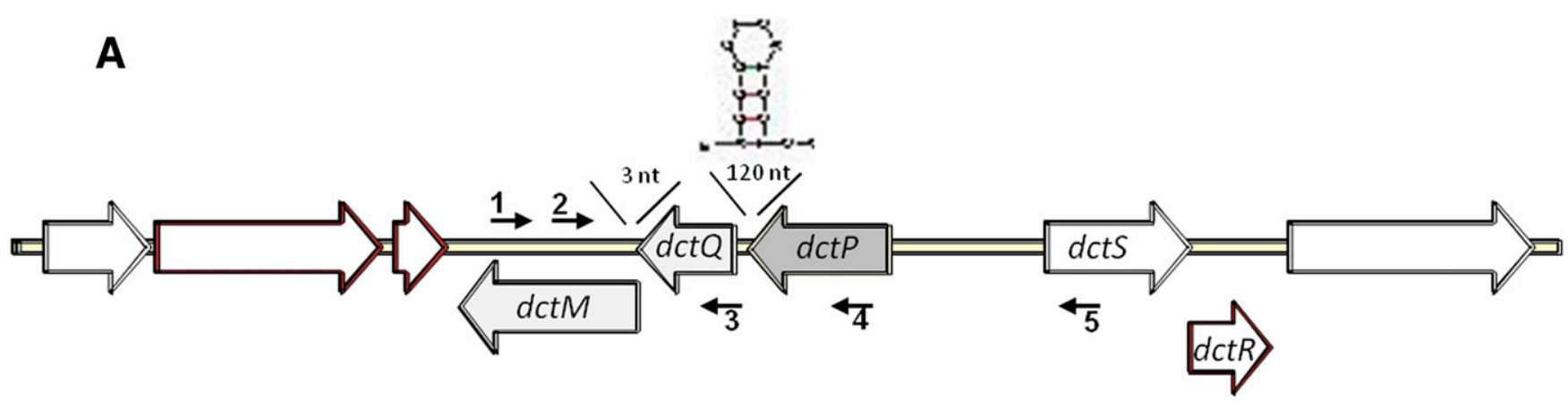

DctP (AZOBR_140140)
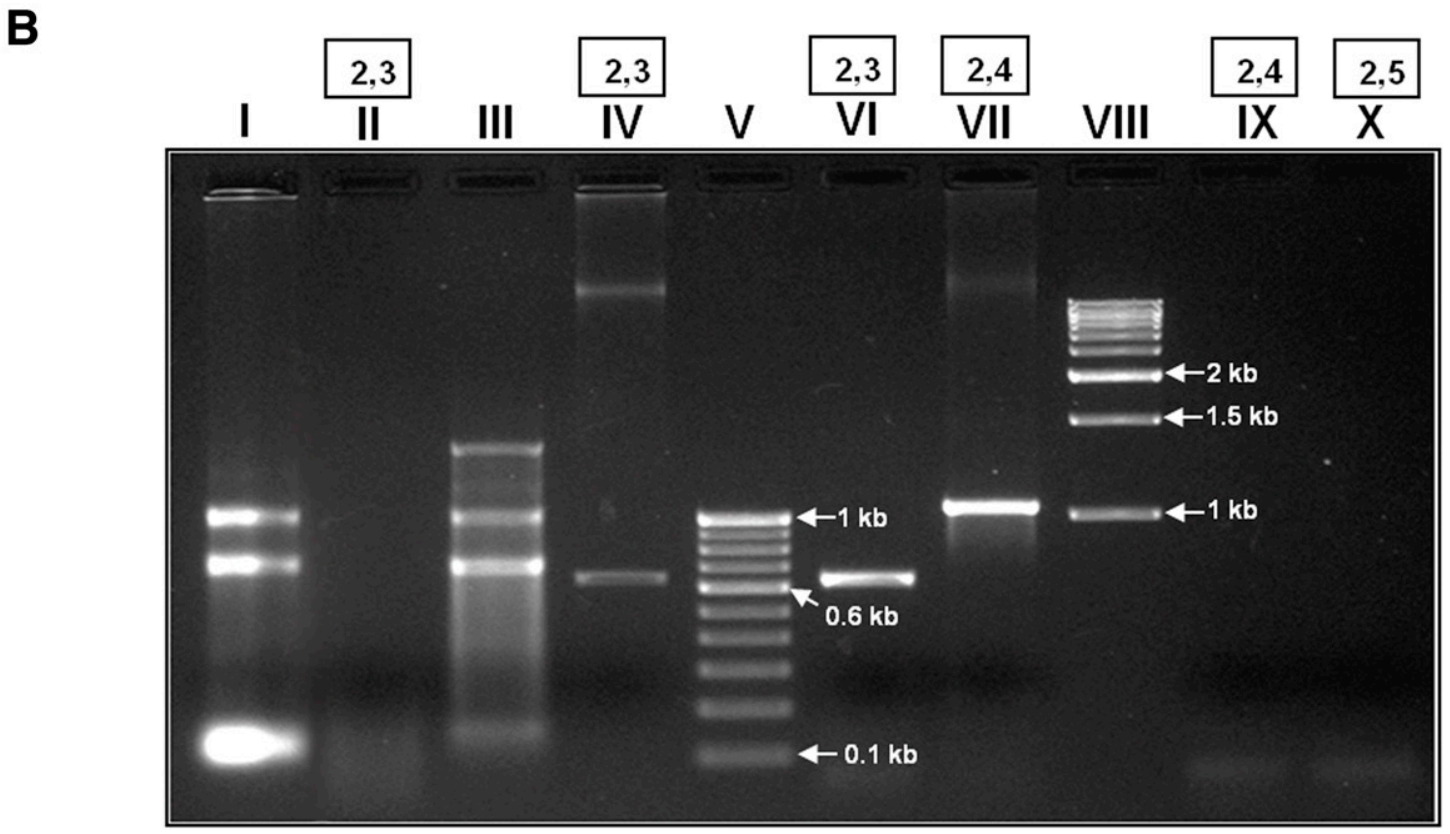

Fig. 2. A, Organization of the $d c t P Q M$ operon and flanking genes in Azospirillum brasilense Sp7. Divergently oriented $d c t S R$ system forms a sensor-regulator pair for the regulation of $d c t P Q M$ operon. A hairpin loop was located in the 120-bp intergenic region between $d c t P$ and $d c t Q$ gene. Large arrows indicate direction of the genes and their orientation while small arrows denote primers used for polymerase chain reaction (PCR) amplification or cDNA synthesis. Primers 1, 2, 3, 4, and 5 indicate primers RTMR1, RTMR2, QRTF, PRTF, and SGF, respectively. B, Electropherogram showing analysis of cotranscription of the $\operatorname{dct} P Q M$ operon. Location of primers is shown along with the results of amplifications shown in the ethidium bromide-stained gel. Lane I shows $1 \mu \mathrm{g}$ of purified RNA isolated from the culture of A. brasilense Sp7 grown in minimum medium with malate as carbon source. Lane II shows results of PCR amplification using primers 2 and 3 with DNase-treated RNA as template (to demonstrate that the RNA used was free from genomic DNA contamination). Lane III shows cDNA $(2 \mu \mathrm{l})$ obtained after the reverse transcription-PCR reaction using primer 1 . Lane IV shows the PCR amplicon produced using primer pair 2,3 with $20 \mathrm{ng}$ of genomic DNA as template; Lane V and Lane VIII show molecular weight markers (Bangalore Genei). Lane VI shows PCR amplification with primer pair 2,3 using cDNA as template. Lane VII shows PCR amplification with primer pair 2,4 using 10 ng of genomic DNA as template. Lane IX shows the result of PCR amplification using primer pair 2,4 with cDNA as template, showing absence of a visible amplicon due to the presence of a hairpin between $d c t P$ and $d c t Q$. Lane $\mathrm{X}$ shows absence of any PCR amplicon with primer pair 2,5 with cDNA as template (showing absence of cotranscription of $d c t S$ with $d c t P Q M$ ). 
affected most adversely, compared with that of the $d c t A:: g m$ or $\operatorname{dct} P:: \mathrm{km}$ mutants. This indicated that DctA and DctP are required for the optimal growth of $A$. brasilense on malate as carbon source.

\section{Effect of inactivation of $\operatorname{dct} A$ and $\operatorname{dct} P$ on nitrogen-fixing ability of $A$. brasilense Sp7.}

Since nitrogen-fixation ability of diazotrophic bacteria depends on their ability to transport dicarboxylates (Driscoll and Finan 1993; Ronson et al. 1981), we carried out an acetylene reduction assay to compare the nitrogen-fixation ability of the three mutants (dctP::km, dctA::gmI, and the double mutant) with that of $A$. brasilense $\mathrm{Sp} 7$ grown with malate as sole carbon source in semisolid medium. Figure 7 shows that nitrogenfixation ability of the double mutant was most adversely affected, whereas that of the $\operatorname{dctP}:: \mathrm{km}$ and $\operatorname{dct} A:: \mathrm{km}$ mutants was relatively less affected individually.

Effect of inactivation of $\boldsymbol{d c t} \boldsymbol{A}$ and $\boldsymbol{d c t P}$ on floc formation.

A. brasilense $\mathrm{Sp} 7$ does not flocculate in medium with a low C: $\mathrm{N}$ ratio $\left(40 \mathrm{mM}\right.$ malate and $10 \mathrm{mM} \mathrm{NH} \mathrm{NH}_{4} \mathrm{Cl}$ ), but it shows extensive flocculation in medium with a high $\mathrm{C}: \mathrm{N}$ ratio $(40 \mathrm{mM}$ malate and $4 \mathrm{mM} \mathrm{NH} \mathrm{NH}_{4}$ ). When floc-forming ability was compared between A. brasilense $\mathrm{Sp} 7$ and its three mutants in $\mathrm{MM}$ with a high C:N ratio, $A$. brasilense $\mathrm{Sp} 7$ and the $\operatorname{dct} A:: g m$ mutant of $A$. brasilense showed very conspicuous floc formation (Fig. 8A and B). Floc formation in the dctA::gm was slightly less than that seen in A. brasilense Sp7, but the double mutant did not show any floc formation, reflecting carbon limitation. Floc formation in the $\operatorname{dct} P:: k m$ mutant was substantially lower than that found in the $d c t A:: g m$ mutant or the double mutant (Fig. 8B).

\section{Effect of inactivation of $\boldsymbol{d c t} A$ and $\operatorname{dct} P$}

on the colonization and growth of roots in finger millet.

The ability of green fluorescent protein $(g f p)$-tagged $A$. brasilense $\mathrm{Sp} 7$ and its mutants to colonize the roots of finger millet was compared by confocal microscopy 10 days after inoculation (Fig. 9). While roots inoculated with untagged $A$. brasilense $\mathrm{Sp} 7$ did not show any green fluorescence, a large number of intense green fluorescing cell clumps or aggregates were observed scattered on the surface of young root zones inoculated with $g f p$-tagged A. brasilense Sp7 (Fig. 9). In the case of the gfp-tagged $d c t A:: g m$ mutant, the number of aggregates and the size of each aggregate were considerably reduced. The number and size of the green fluorescing flocs was drastically reduced when $g f p$-tagged $d c t P:: k m$ mutant was used for inoculation, although some colonization could be seen in the root-cap region. In the case of the double mutant, however, green fluorescing flocs were completely absent in the cortical region. Some feeble green fluorescence was observed in the root-cap region.

The effect of inoculation of A. brasilense Sp7 and its three $d c t$ mutants on the root system of the finger millet seedlings was observed 20 days after bacterial inoculation. Figure 10A shows the difference in the root morphology of the seedlings with different bacterial treatments. There was a distinct difference in the length of the primary root between uninoculated and the seedlings inoculated with $A$. brasilense Sp7. The most visible difference was seen on the number of secondary roots

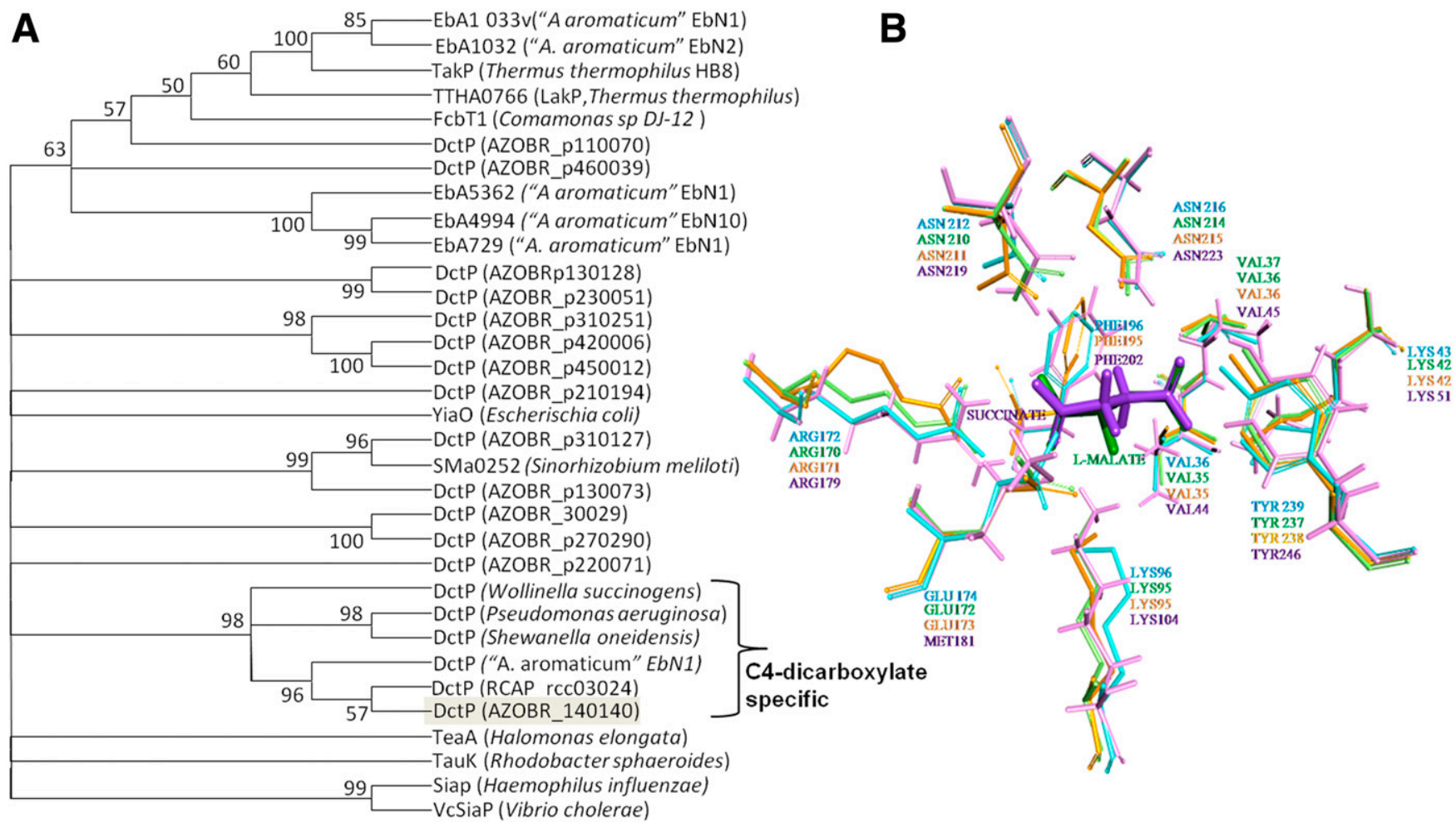

Fig. 3. A, Phylogram of multiple DctP paralogs of Azospirillum brasilense Sp7 and some other characterized orthologs. Amino acid sequences of DctP homologs were aligned using the ClustalW program, and a phylogenetic tree was constructed with MEGA 7 software using the maximum likelihood method based on the JTT matrix-based model, using 1,000 bootstrap replications to represent evolutionary history of the taxa analyzed. Branches with less than 50\% bootstrap replicates were collapsed. B, Representation of active site residues of DctP protein interacting with L-malate and succinate in Pseudomonas aeruginosa (Protein Data Bank [PDB] ID: 4NF0) (green), Shewanella oneidensis (PDB ID: 4MX6) (magenta) and corresponding conserved residues in A. brasilense (orange) and Rhodobacter capsulatus (cyan) DctP homologs. 
emerging from the primary roots (Fig. 10A and B). Roots of the seedlings inoculated with the $\operatorname{dct} A:: g m$ mutant did not show a significant difference from the root morphology of the seedlings inoculated with $A$. brasilense Sp7. Seedlings inoculated with $d c t P:: k m$ mutant and the double mutant showed a distinct decline in the number of secondary roots in comparison with those inoculated with $A$. brasilense $\mathrm{Sp} 7$ or $\operatorname{dct} A:: g m$ mutant (Fig. 10B).

\section{DISCUSSION}

Malate is often the most dominant organic acid found in the root exudates of $\mathrm{C} 4$ grasses. It was shown to be the strongest chemoattractant as well as a preferred source of carbon for the growth of A. brasilense (Alexandre et al. 2000). Chemotactic responses of rhizosphere bacteria toward organic acids correlate with the exudation of these acids by their host plants (Reinhold et al. 1985). Therefore, chemotaxis toward malate and the ability to efficiently utilize it provide a competitive advantage to bacteria that colonize the rhizosphere of $\mathrm{C} 3$ and $\mathrm{C} 4$ grasses, which release a considerable amount of malate in their root exudates (Rudrappa et al. 2008; Vranova et al. 2013). Exudation of organic acids like malate and citrate by plant roots also helps in enhancing the availability of phosphorus and iron and in conferring aluminum tolerance to the host plant (MoraMacías et al. 2017).

The importance of malate for A. brasilense is also reflected by the occurrence of DctPQM (AZOBR_140140) and DctA dicarboxylate transporters, which were found to be important for growth on dicarboxylates. In addition, A. brasilense harbors several other DctPQM paralogs (other than AZOBR_140140) that might have reduced affinity to dicarboxylates and, hence, might be involved in the transport of dicarboxylates at a low level, as they do not contain all the residues required for the binding of dicarboxylates. DetP paralogs other than AZOBR_140140 might be involved in the transport of substrates other than dicarboxylates, as they cluster with TRAP transporters involved in the transport of gluconate, 2-oxybutyrate, 2,3-diketo-L-gulonate, ectoine, 5hydroxyectoine, $N$-acetylneuraminic acid, taurine, $\alpha$-keto acids, glutamate, lactate, 4-chlorobenzoate, and protocatechuate (Mulligan et al. 2011; Okon et al. 1980). Although multiple paralogs of DctP were found in Sinorhizobium meliloti, Corynebacterium glutamicum, Aromatoleum aromaticum, and P. aeruginosa, only one in each was involved in the transport of dicarboxylates (Forward et al. 1997).

It was intriguing to see that DctP was the most prominently upregulated protein in the SDS-PAGE of the total proteins of the malate-grown cells of $A$. brasilense, but the expected protein band of the other two proteins (DctQ, $25 \mathrm{kDa}$, and DctM, $47.5 \mathrm{kDa}$ ) constituting the TRAP transporter were not visible. The presence of a hairpin loop immediately downstream of $d c t P$ in the intergenic region between $\operatorname{dct} P$ and $\operatorname{dct} Q M$ might reduce the frequency of cotranscription quite substantially. In the case of $R$. capsulatus also, DctP was the most abundant protein in SDS-PAGE but DctQ and DctM were much less abundant (Shaw and Kelley 1991). Transcript analysis of the RNA isolated from malate-grown $R$. capsulatus by Northern hybridization with the $\operatorname{dct} P$ probe revealed an abundance of 1-kb transcript (from $d c t P$ ) and a low abundance of 3-kb transcript (derived from $\operatorname{dctPQM}$ ) (Shaw and Kelley 1991). Presence of a GC-rich region of dyad symmetry with potentially stable stem-loop structure between $d c t P$ and $d c t Q M$ in R.capsulatus was thought to be responsible for creating a partial transcriptional terminator permitting very little read-through. This is why the $\operatorname{dct} P$ insertion mutant could be complemented with $d c t P Q M$ only and not with $d c t P$ alone. Here also, $d c t P:: k m$
A

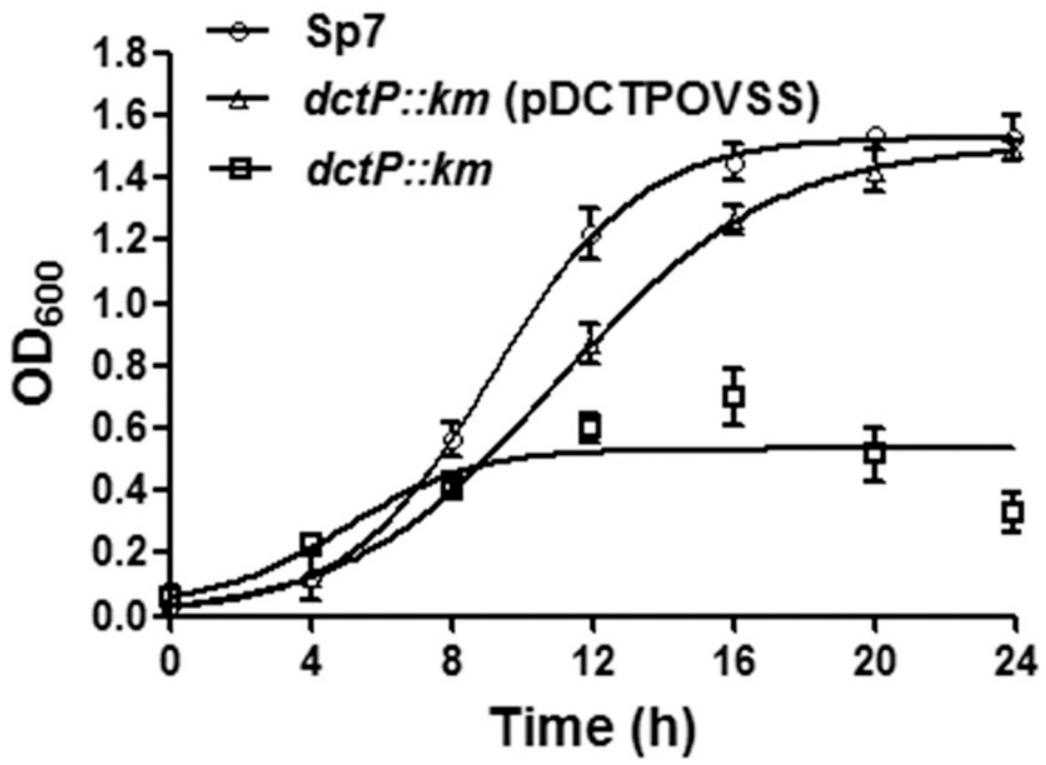

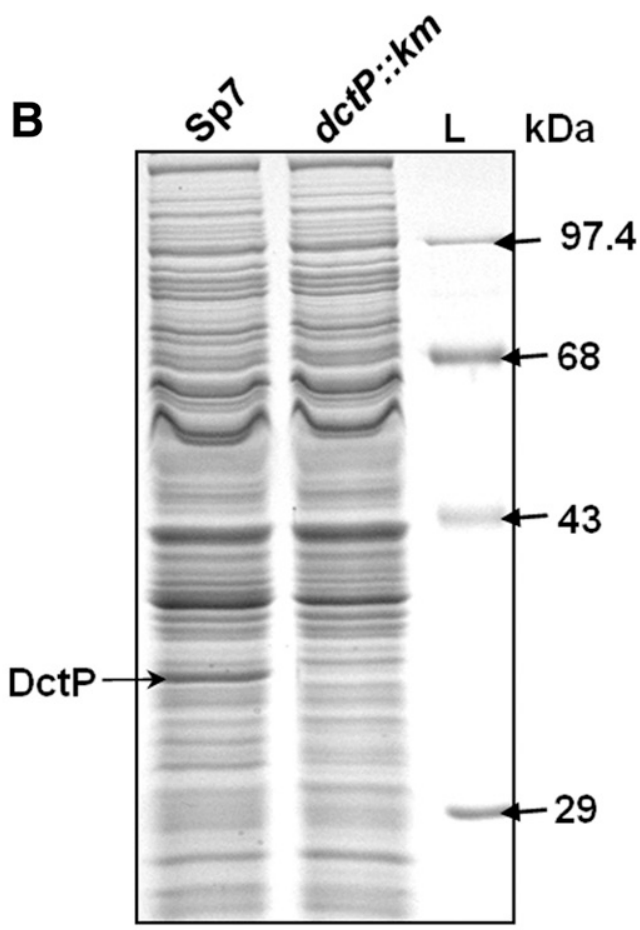

Fig. 4. A, Growth curves of Azospirillum brasilense $\mathrm{Sp} 7, \operatorname{dct} P:: k m$ mutant, and $d c t P:: k m$ mutant strains complemented with the cloned copy of the $d c t P Q M$ operon in minimal medium (MM) containing malate $(40 \mathrm{mM})$ as carbon source. Mean \pm standard deviation of three independent experiments, each performed in triplicate, are indicated. B, Sodium dodecyl sulfate-polyacrylamide gel electrophoresis (12\%) showing presence of malate-inducible DctP protein in A. brasilense $\mathrm{Sp} 7$ and its absence in the $\operatorname{dct} P:: \mathrm{km}$ mutant, respectively. Every lane of the gel was loaded with $20 \mu \mathrm{g}$ of total protein obtained from A. brasilense Sp7 and its $d c t P:: \mathrm{km}$ mutant grown in MM containing malate $(40 \mathrm{mM})$ as carbon source. Lane L shows protein molecular weight marker (Banglore genei). 
mutant could be complemented with the complete $\operatorname{dct} P Q M$ operon but not $\operatorname{dct} P$ alone.

The $\operatorname{dct} P:: \mathrm{km}$ mutant of $A$. brasilense $\mathrm{Sp} 7$ showed the same initial speed of growth on malate as the parent but stopped growing after $8 \mathrm{~h}$, eventually leading to a decline. The $\operatorname{dct} A:: \mathrm{gm}$ mutant initially grew more slowly than the parent but ultimately reached the same level of growth. This difference may be due to the difference between the affinity of DctA and DctP toward dicarboxylates (Valentini et al. 2011). These observations
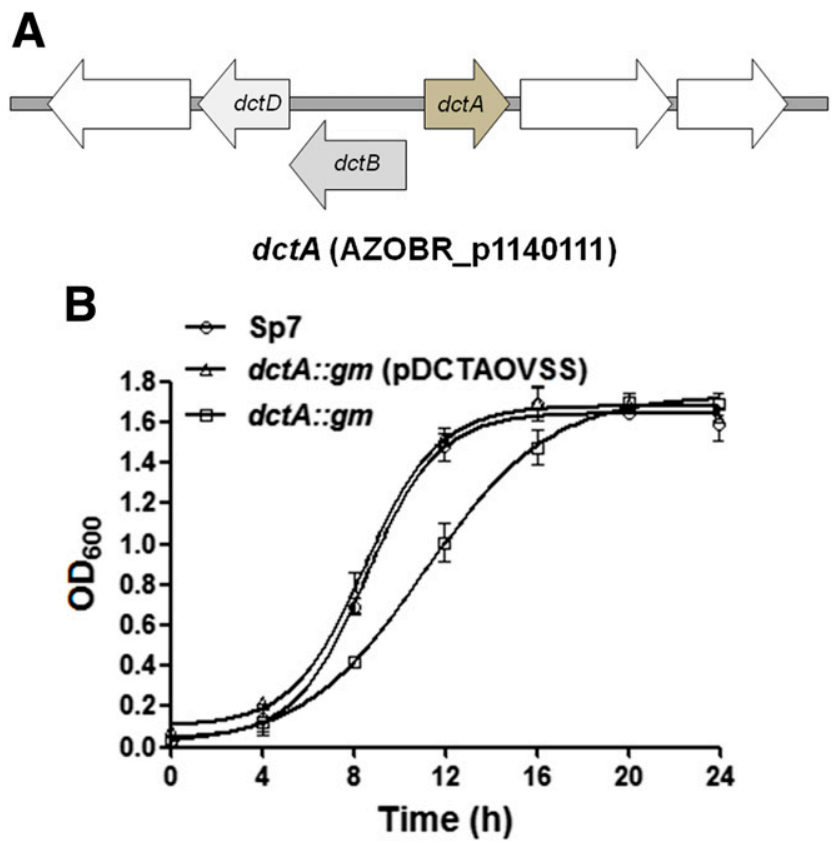

Fig. 5. A, Schematic representation of the organization of genes around dctA of Azospirillum brasilense Sp7. The divergently oriented dctBD system forms a sensor-regulator pair of the DctA transporter. B, Growth curves of A. brasilense Sp7, the dctA::gm mutant, and $d c t A:: g m$ complemented with a cloned copy of the $d c t A$ gene in minimum medium containing malate $(40 \mathrm{mM})$ as sole carbon source. Each point of the curves represents mean of the triplicates from three independent experiments, and the error bars at each point show standard deviation.

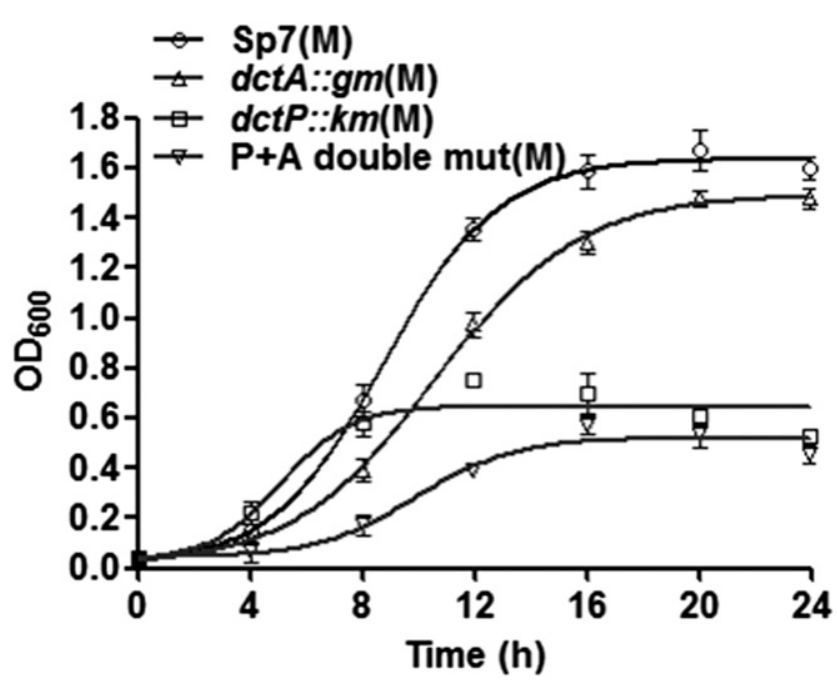

Fig. 6. Growth curves of Azospirillum brasilense Sp7, dctA::gm, dctP::km, and the double mutant of $A$. brasilense $\mathrm{Sp7}$ grown in minimal medium containing malate $(40 \mathrm{mM})$ as carbon source. Each point of the curve shows mean of the triplicates from three independent experiments, and the error bars at each point indicate standard deviation. suggest that the two transport systems play different roles. Significantly reduced diazotrophic growth and nitrogen-fixing ability of the $\operatorname{dctP}:: \mathrm{km}$ mutant and the double mutant of A. brasilense $\mathrm{Sp} 7$ in the medium containing malate as sole carbon source indicated the importance of dicarboxylates as a primary source of carbon for nitrogen fixation in A. brasilense. Cells require significant amounts of carbon to produce cell-wall polysaccharides in order to form flocs or aggregates (Burdman et al. 1998; Sadasivan and Neyra 1985). The drastically reduced ability of $d c t P:: \mathrm{km}$ and the double mutant to form flocs or aggregates in the culture medium with a high $\mathrm{C}: \mathrm{N}$ ratio suggests that the defect in the dicarboxylate transporters might reduce the effective intracellular concentration of malate in the high C:N ratio medium. The reduced uptake of malate by the mutants may mimic the response of $A$. brasilense $\mathrm{Sp} 7$ in a low $\mathrm{C}: \mathrm{N}$ ratio medium, which may be the cause for decline in flocculation by the mutants in spite of a high $\mathrm{C}: \mathrm{N}$ ratio culture medium (Bible et al. 2012; Burdman et al. 1998). The decline of flocculation in the $d c t P:: \mathrm{km}$ and the double mutant observed in this study clearly follows the decline in the availability of carbon to the bacterium.

In rhizobia, dicarboxylate transport plays an important role in the operation of an effective, nitrogen-fixing symbiosis (Watson et al. 1988). DctA is the only transporter of dicarboxylates that is found to be essential for in-planta nitrogen fixation, as nodules infected with $d c t A$ mutants fail to fix nitrogen due to their inability to utilize dicarboxylates (Engelke et al. 1989; Jording et al. 1994; Reid and Poole 1998). Although dctPQM homologs are present in Sinorhizobium meliloti, they are not involved in the transport of dicarboxylates (Yurgel and Kahn 2004, 2005). In $R$. capsulatus, DctP along with DctQM constitutes a dicarboxylate transporter that is solely responsible for the transport of dicarboxylates (Forward et al. 1997). Sinorhizobium meliloti mutants having deletion of $\operatorname{dct} A B D$ genes, but expressing dctPQMSR genes from $R$. capsulatus were able to grow on dicarboxylates (Forward et al. 1997). This further confirmed that $R$. capsulatus dctPQMSR genes encoded a complete dicarboxylate transport system, which is absent in Sinorhizobium meliloti (Forward et al. 1997). P. aeruginosa uses both DctA and DctPQM type of dicarboxylate transport

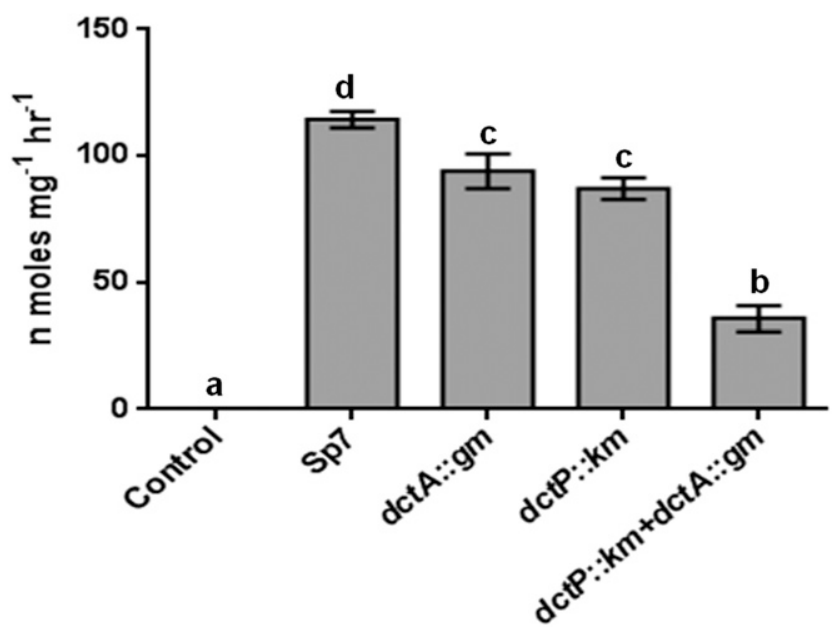

Fig. 7. Comparison of the acetylene reducing ability of Azospirillum brasilense Sp7, dctA::gm, dctP::km, and the double mutant after $24 \mathrm{~h}$ of growth in nitrogen-free semisolid minimum medium containing malate $(40 \mathrm{mM})$ as carbon source. Mean \pm standard deviation of triplicates from three experiments is indicated, and differences between means were calculated. Small letters above the bars represent a homogeneous subset of the treatments and indicate the result of Duncan's multiple range test (different letters have $P$ values of $<0.05)$. 
systems for utilizing dicarboxylates (Valentini et al. 2011). This study also indicated that $A$. brasilense uses both DctPQM and DctA for its growth and nitrogen fixation on dicarboxylate. The genome of $A$. aromaticum does not harbor any gene encoding DctA. It, however, encodes six paralogs of DctP, and the paralog having maximum identity with the DctP of $R$. capsulatus was the most abundant protein in dicarboxylate grown

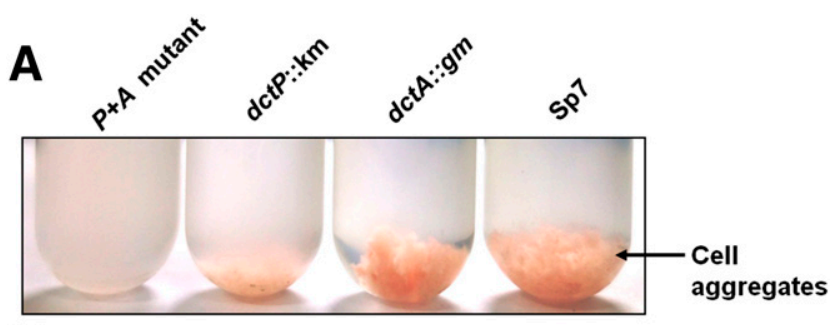

B

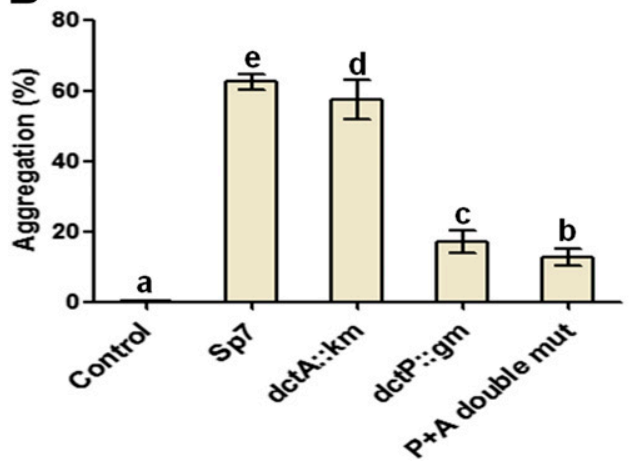

Fig. 8. A, Comparison of aggregation of Azospirillum brasilense Sp7, dctA: $\mathrm{gm}, \operatorname{dct} P:: \mathrm{km}$, and the double mutant under N-limited growth conditions. B, Bar diagram shows percentage of cell aggregation of A. brasilense $\mathrm{Sp} 7$, $\operatorname{dct} A:: \mathrm{gm}, \operatorname{dct} P:: \mathrm{km}$, and the double mutant grown in minimum medium supplemented with $40 \mathrm{mM}$ malate and $4 \mathrm{mM} \mathrm{NH} \mathrm{ml}_{4} \mathrm{Cl}$. Mean \pm standard deviation of triplicates from the three experiments is indicated, and the difference between means were calculated. Small letters above the bars represent a homogeneous subset of the treatments and indicate the result of Duncan's multiple range test (different letters have $P$ values of $<0.05$ ). cultures (Trautwein et al. 2012). The genome of Corynebacterium glutamicum encodes three paralogs of DctA and three encoding TRAP transporters (DctPQM). Surprisingly, none of them is involved in dicarboxylate transport (Teramoto et al. 2008). DcsT protein of the DASS family, however, was found to be responsible for the aerobic growth of Corynebacterium glutamicum on dicarboxylates.

Azospirillum spp. have been shown to colonize plant roots, using various techniques including electron microscopy, immunofluorescence microscopy, $\beta$-glucuronidase (GUS)-tagging, and GFP-tagging coupled with confocal laser scanning microscopy (Bashan and Lavanony 1989; Okon and Kapulnik 1986; Ramos et al. 2002; Schank et al. 1979; Umali-Garcia et al. 1980; Vande Broek et al. 1993). Colonization of wheat roots by $A$. brasilense, using a GUS reporter system, had shown that root colonization by $A$. brasilense was initiated in the root-hair zones and the sites of emergence of lateral roots (Vande Broek et al. 1993). The process of attachment of Azospirillum spp. to the root surface starts with an initial loose binding, followed by a firm binding, and, then, entrapment of additional bacteria to form large bacterial aggregates (Michiels et al. 1991). In a study of Azospirillum-wheat interaction using $g f p$ and $g u s A$ genes, cell aggregates and single bacteria were visualized on the surface of the plant root system, including root hairs, lateral roots, and points of emergence of lateral roots (Ramos et al. 2002). We also found a large number of aggregates of GFPtagged $A$. brasilense at the root tip and in the zone of root elongation on the roots of finger millet.

We also noted a significant decline in the number of secondary roots of the seedlings inoculated with $\operatorname{dctP}:: \mathrm{km}$ and the double mutant of $A$. brasilense $\mathrm{Sp} 7$, vis-a-vis those inoculated with $\operatorname{dct} A:: g m$ and A. brasilense Sp7. As expected, in comparison with the uninoculated seedlings, the roots inoculated with $A$. brasilense $\mathrm{Sp} 7$ showed a major increase in the number of secondary roots and, also, a notable difference in the length of the primary root. The difference in root morphology may be assigned to the ability of $A$. brasilense and its $d c t$ mutants to proliferate on the roots and to produce a proportionate amount of auxins to cause secondary root formation. Also, earlier, A. brasilense was shown to colonize the roots of finger millet and pearl millet, leading to considerable increases in yield
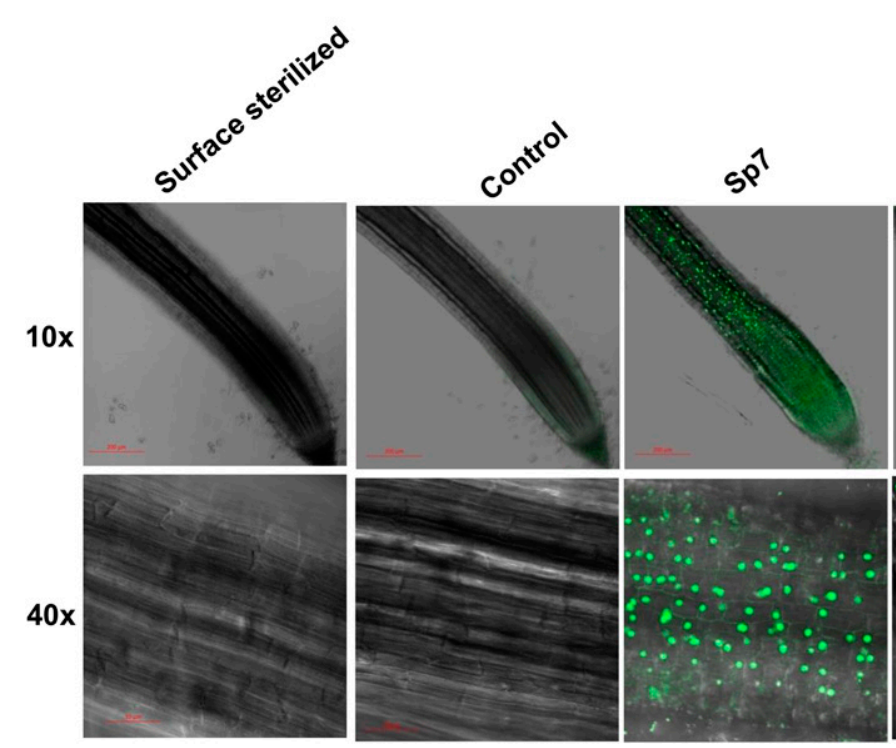
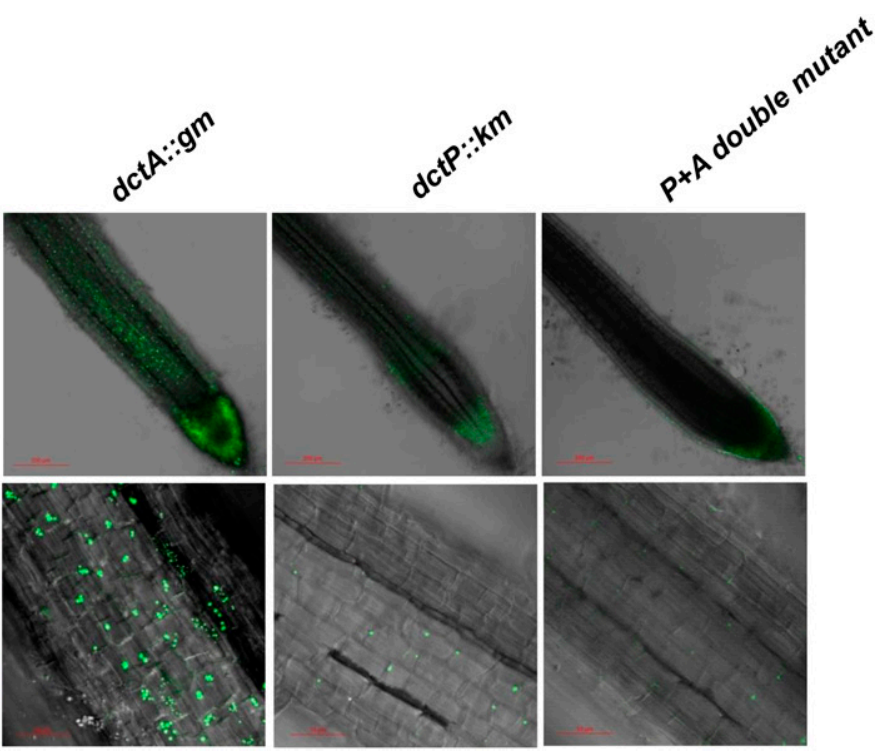

Fig. 9. Confocal laser scanning microscopy images (10 and 40×) of surface-sterilized root, gfp-tagged Azospirillum brasilense Sp7, dctA::gm, dctP::km, and the double mutant on the roots of Eleusine coracana 10 days after inoculation. Control shows roots inoculated with equal amount of untagged A. brasilense Sp7. Cells expressing green fluorescent protein are green and gray background corresponds to root image formed by transmitted light. 
(Agarwala and Tilak 1988; Rai 1991; Subba Rao 1985; Tilak and Subba Rao 1987; Umali Garcia et al. 1980; Wani et al. 1985). There could be two reasons for the failure of the $\operatorname{dctP}:$ : $\mathrm{km}$ mutant and the double mutant to colonize the roots of finger millet. The primary reason for the failure of the mutants to colonize plant roots is the severely compromised ability of the $\operatorname{dctP}:: \mathrm{km}$ mutant and the double mutant to utilize dicarboxylates for growth and nitrogen fixation. Another reason for their failure to colonize finger millet roots could be the lack of their ability to form flocs or cell aggregates, which are considered important in plant root colonization (Burdman et al. 1998).

Plants control the populations of associated fungi and bacteria in their rhizosphere by releasing root exudates (Bardgett et al. 2014; Coskun et al. 2017). Azospirillum strains have been shown to display chemotaxis toward several amino acids, sugars, organic acids (Barak et al. 1983; Okon et al. 1980; Reinhold et al. 1985), root exudates (Heinrich and Hess 1985), and root mucilage (Mandimba et al. 1986). It was hypothesized that specific compounds are secreted in the root hair zones of wheat roots to which Azospirillum species are attracted. Since biological nitrogen fixation is an energy-intensive process, availability of carbon sources in the rhizosphere is one of the major limiting factors for associative nitrogen fixation. In this study, we have provided evidence to corroborate a long-held belief that dicarboxylates play an important role in plant root colonization and associative nitrogen fixation by Azospirillum spp. The first evidence in support of this was obtained in a wheat cultivar that released higher amounts of $\mathrm{C} 4$ dicarboxylates in its root exudates and also showed significantly higher

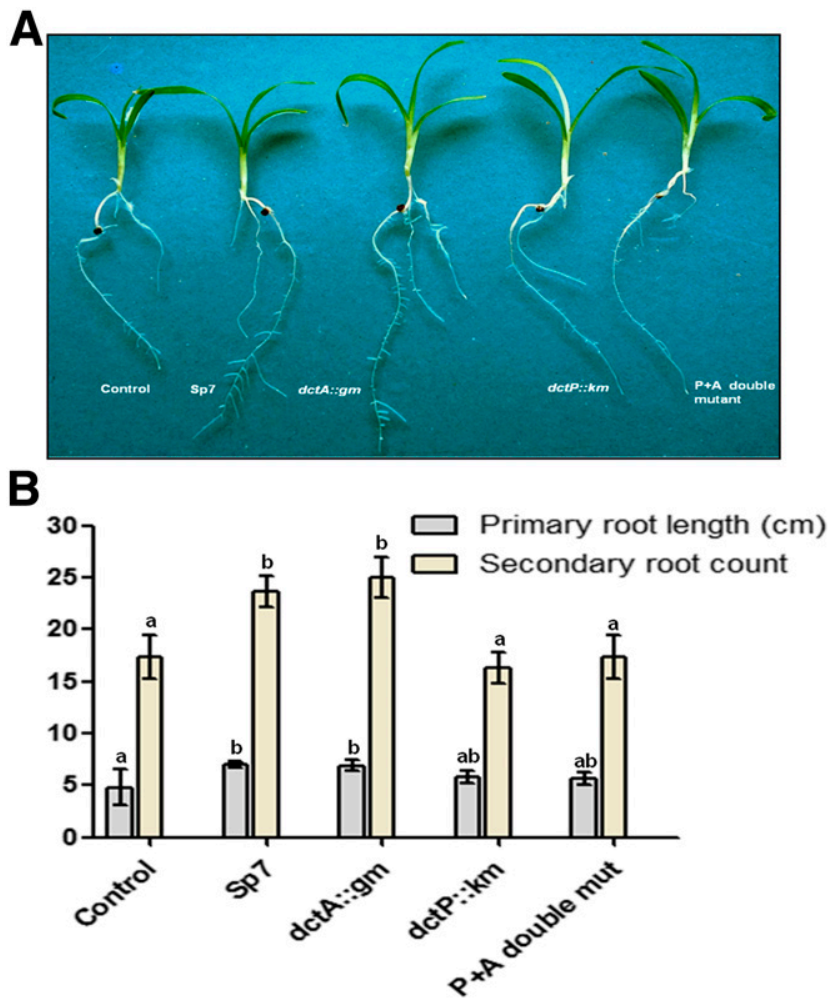

Fig. 10. Comparison of the roots of the seedlings of Eleusine coracana plants after 20 days of bacterial inoculation of Azospirillum brasilense Sp7 and its $d c t$ mutants $\mathbf{A}$, Effect of inoculation of $A$. brasilense $\mathrm{Sp} 7$ and its $d c t$ mutants on root length and morphology. B, Measurement of primary root length and numbers of secondary roots. Mean \pm standard deviation of the replicates is indicated, and differences between mean were calculated. Small letters above the bars represent a homogeneous subset of the treatments and indicate the result of Duncan's multiple range test (different letters have $P$ values of $<0.05)$. nitrogen fixation by $A$. brasilense and transfer of fixed nitrogen to the host plant than the wheat cultivar releasing a low amount of dicarboxylates in its root exudates (Christiansen-Weniger 1992). Mutants of A. brasilense with defects in motility and chemotaxis were used earlier to establish the role of bacterial motility in Azospirillum-plant root association (Vande Broek et al. 1998). We have shown here that A. brasilense mutants having defects in their ability to utilize dicarboxylates show considerably reduced growth and nitrogen fixation on dicarboxylates and possess reduced ability to colonize the roots of finger millet. This is the first study demonstrating the importance of dicarboxylate transporters of $A$. brasilense in colonizing the roots of a $\mathrm{C} 4$ grass and in promoting proliferation of the root system. These observations pave the way for a relatively longerterm experiment using a $15 \mathrm{~N}$ isotope dilution technique to demonstrate the contribution of $A$. brasilense to the nitrogen needs of the nonlegume plants through dicarboxylate-dependent nitrogen-fixation by A. brasilense (Hardarson and Hera 1998).

\section{MATERIALS AND METHODS}

\section{Bacterial strains, culture condition, plasmids,} and chemicals.

Bacterial strains and plasmids used in study are described in Table 1. A. brasilense Sp7 was grown and maintained in $\mathrm{MM}$ containing $40 \mathrm{mM}$ malate as carbon source and $18 \mathrm{mM} \mathrm{NH}_{4} \mathrm{Cl}$ as nitrogen source (Albrecht and Okon 1980) at $30^{\circ} \mathrm{C}$. For experiments, overnight-grown cultures of $A$. brasilense in Luria-Bertani (LB) (Miller 1972) or in MM with $40 \mathrm{mM}$ fructose (instead of malate) as sole carbon source were pelleted, were washed with $0.85 \%$ saline, and were then reinoculated in $\mathrm{MM}$ supplemented with different $\mathrm{C}_{4}$-dicarboxylates (each $40 \mathrm{mM}$ ) as the sole source of carbon. E. coli strains like DH5 $\alpha$ and S17-1were grown in LB medium at $37^{\circ} \mathrm{C}$. All chemicals and media components used for growing bacteria were purchased from Hi-Media, Merck, or Sigma Aldrich. Restriction enzymes, DNA ligase, Taq polymerase, Phusion high fidelity DNA polymerase, DNase, RNase, and alkaline phosphatase were purchased from New England Biolabs. As required, ampicillin $(100 \mu \mathrm{g} / \mathrm{ml})$, chloramphenicol $(20 \mu \mathrm{g} / \mathrm{ml}), \mathrm{Km}(30$ $\mu \mathrm{g} / \mathrm{ml}), \mathrm{Gm}(10 \mu \mathrm{g} / \mathrm{ml})$, and tetracycline $(10 \mu \mathrm{g} / \mathrm{ml})$ were added in the medium for A. brasilense $\mathrm{Sp} 7$ and its derivatives.

\section{Analysis of bacterial growth.}

The growth of $A$. brasilense $\mathrm{Sp} 7$ was monitored in $\mathrm{MM}$ supplemented with malate, succinate, fumarate, or fructose (each 40 or $20 \mathrm{mM}$ ) as sole carbon source at $30^{\circ} \mathrm{C}$ with shaking at $180 \mathrm{rpm}$. Overnight-grown primary cultures of A. brasilense (in LB medium) were pelleted, were washed with $0.85 \%$ saline, and were reinoculated in secondary MM supplemented with $\mathrm{C}_{4}$-dicarboxylates and fructose $(40 \mathrm{mM})$ as the sole carbon source. Growth was monitored by recording $\mathrm{OD}_{600}$ at $4 \mathrm{~h}$ intervals and growth curves were plotted OD versus time. Growth curves of A. brasilense Sp7, its mutants $(\operatorname{dctP}:: \mathrm{km}$, dctA::gm and double knockout mutant), and complemented strains (the $d c t P:: k m$ mutant harboring the pDCTPOVSS plasmid and the dctA::gm mutant harboring the pDCTAOVSS plasmid) were also plotted as above.

\section{Effect of different carbon compounds on protein profile.}

Overnight-grown culture of $A$. brasilense $\mathrm{Sp} 7$ in LB broth was pelleted, was washed, and was reinoculated in the MM supplemented with malate, succinate, fumarate, or fructose (each $40 \mathrm{mM}$ ) as a sole source of carbon. When cultures reached the late $\log$ phase, $8 \mathrm{ml}$ of each culture was pelleted by centrifugation and pellets were resuspended in $1 \mathrm{ml}$ of $1 \times$ phosphate buffered saline containing $1 \mathrm{mM}$ phenylmethylsulfonyl fluoride. 
The cell pellets were lysed by sonication for $5 \mathrm{~min}$, at 9-s on/off conditions, at $4^{\circ} \mathrm{C}$. The resulting lysate was centrifuged at $14,000 \mathrm{rpm}$ at $4^{\circ} \mathrm{C}$ and supernatant was collected for protein estimation by Bradford assay (Bradford 1976). Protein lysate $(20 \mu \mathrm{g}$ of each) was mixed with equal volume of $2 \times$ protein cracking dye, was boiled at $95^{\circ} \mathrm{C}$ for $10 \mathrm{~min}$, followed by a brief vortex and centrifugation. The protein samples $(20 \mu \mathrm{g}$ per lane) were then loaded in precast $12 \%$ SDS-PAGE and electrophoresis was performed at $150 \mathrm{~V}$ for $5 \mathrm{~h}$. A $37-\mathrm{kDa}$ protein that was most prominently upregulated in the malate-grown cells was analyzed by MALDI-tandem mass spectrometry (MS/MS) after trypsin digestion. The predicted peptide sequences were searched in the genome of $A$. brasilense Sp245.

\section{Bioinformatic analysis.}

The amino acid sequence of the induced DctP (AZOBR_140140) and DctA (AZOBR_p1140111) of A. brasilense Sp7 were retrieved from the Genoscope database, and similar sequences from other bacteria were retrieved from the National Center for Biotechnology Information database. Levels of sequence identity and similarity were calculated using multiple sequence alignment tools at the European Bioinformatics Institute server. A phylogenetic tree was constructed using the MEGA 7 software by the maximum likelihood method based on a JTT matrix-based model (Jones et al. 1992), using 1,000 bootstrap replications to represent evolutionary history of the taxa analyzed. Structure modeling, superposition, and docking experiments were done on the Discovery Studio 3.5 Suite. Gene analysis and construction of genetic organization were performed with the help of vector NTI (Thermo Fisher Scientific) software.

\section{RT-PCR.}

Total RNA was isolated from A. brasilense Sp7 cells grown in minimal malate medium using the TRIzol method. RNA isolation and cDNA synthesis were performed according to a method described elsewhere (Mishra et al. 2011). After treatment with RNase-free DNase (Thermo) for $1 \mathrm{~h}$ at $37^{\circ} \mathrm{C}$, RT-PCR was carried out with $2 \mu \mathrm{g}$ of RNA sample and $d c t M$-specific primer RTMR1 (Table 2), using the One Step RT-PCR kit (Thermo) according to manufacturer instructions. The cycle condition used was $45^{\circ} \mathrm{C}$ for $60 \mathrm{~min}$, followed by heat inactivation at $72^{\circ} \mathrm{C}$ for $10 \mathrm{~min}$. Negative and positive controls were included in RT-PCR for checking DNA contamination and primer functionality.
Construction of the $\operatorname{dct} P$ :lac $Z$ transcriptional fusion.

In order to study the inducibility of $\operatorname{dctP}$ (AZOBR_140140) promoter in response to various carbon compounds, transcriptional $l a c Z$ fusion with $d c t P$ promoter region was constructed. The upstream regions of the $\operatorname{dctP}(156 \mathrm{bp})$ gene from $A$. brasilense $\mathrm{Sp} 7$ was $\mathrm{PCR}$-amplified using a set of primers (DCTPPF and DCTPPR [Table 2]) containing XbaI and HindIII sites in forward and reverse primers, respectively. The amplicon was cloned in pCZ750 vector (Dombrecht et al. 2001) digested with $X b a \mathrm{I}$ and HindIII. Once the recombinant plasmid was confirmed by colony PCR and restriction digestion, it was isolated and was transformed in E. coli S17.1, which was used as a donor for the conjugative mobilization of the recombinant plasmid (pVSSPP [Table 1]) in A. brasilense Sp7.

\section{$\boldsymbol{\beta}$-Galactosidase assay.}

The effect of various $\mathrm{C}_{4}$-dicarboxylates on the inducibility of $d c t P$ gene was monitored by assaying $\beta$-galactosidase activity of the cultures of $A$. brasilense Sp7 (pVSSPP) grown with 40$\mathrm{mM}$ concentrations of each carbon source at $30^{\circ} \mathrm{C}$, with shaking, at $180 \mathrm{rpm}$. After $6 \mathrm{~h}$ of growth, samples of $0.5 \mathrm{OD}_{600}$ were collected by centrifugation and a $\beta$-galactosidase assay of equal numbers of cells of each sample was performed (Miller 1972).

Table 2. Primers used in this study

\begin{tabular}{ll}
\hline Primers & \multicolumn{1}{c}{ Sequence 5' to $\mathbf{3}^{\prime}$ direction } \\
\hline DCTPPF & GCTCTAGAGTCATCCTCCACTTGTTGTTGG \\
DCTPPR & CCCAAGCTTCTGGCCGCACCGCCGGTCATGG \\
PAF & AACTGCAGGTTCATCGGTCGTTCTCCTTCG \\
PAR & GAAGATCTCGTCCAACATGTACACCCAGAAG \\
PBF & GAAGATCTTGTCCTCCTTGTCCTTGTAGAGC \\
PBR & GGAATTCGGCCGGGATTCACATAGATGAT G \\
GSPF & CCCAAGCTTGATTGCTCCGACGAGGG \\
GSPR & CGGGATCCATGAAGTTCGTTTCGCTGC \\
AAF & CCGGAATTCTGCGCAGGTTGGATTCGTACAG \\
AAR & GAAGATCTAGGAAGTCGATGGTCGTGTGG \\
ABF & GAAGATCTGCAAGTACGGCGTGTCGTCG \\
ABR & AAAACTGCAGGGACGATGGTGTCGACCAGAC \\
GSAF & CGCGGATCCAACATGCACGCCCAAGGGCAG \\
GSAR & CCCAAGCTTGTCAGATGCGGGCCCCAGAG \\
RTMR1 & ACAGCTTCAGCGCCACG \\
RTMR2 & GTCATGGTGAAGAGGAAGGTC \\
QRTF & CTGCATCTACATGTTCGTCTGG \\
PRTF & TCTACGAGCTGACCAAGGACG \\
SGF & AGAGGTGTTGGCACGGCAACC \\
\hline
\end{tabular}

Table 1. Bacterial strains and plasmids

\begin{tabular}{|c|c|c|}
\hline Strains and plasmids & Relevant properties ${ }^{\mathbf{a}}$ & References/Sources \\
\hline Escherichia coli $\mathrm{DH} 5 \alpha$ & DlacUl 69 hsdRl 7 recAl endA1 gyrA96 thiL relA1 & Gibco BRL \\
\hline E. coli $\mathrm{S} 17-1$ & $\mathrm{Sm}^{\mathrm{r}}$, recA, thi, pro, hsdR-M+RP4:2-Tc:Mu:Km Tn7, גpir & Simon et al. 1983 \\
\hline Azospirillum brasilense $\mathrm{Sp} 7$ & Wild-type strain (ATCC 29729) & Nur et al. 1981 \\
\hline $\operatorname{dctP}:: \mathrm{km}$ & A. brasilense $\mathrm{Sp} 7$ dctP (AZOBR_140140) gene disrupted by insertion of $\mathrm{Km}^{\mathrm{r}}$ cassette & This work \\
\hline $\operatorname{dctA}:: g m$ & A. brasilense $\mathrm{Sp} 7$ dctA (AZOBR_p1140111) gene disrupted by insertion of $\mathrm{Gm}^{\mathrm{r}}$ cassette & This work \\
\hline $\begin{array}{l}d c t P:: k m, \operatorname{dct} A:: g m \\
(\mathrm{P}+\mathrm{A} \text { double mutant })\end{array}$ & $\begin{array}{l}\text { A.brasilense } S p 7 d c t P\left(A Z O B R \_140140\right) \text { and } d c t A\left(A Z O B R \_p 1140111\right) \text { genes disrupted by } \\
\text { insertion of } \mathrm{Km}^{\mathrm{r}} \text { and } \mathrm{Gm}^{\mathrm{r}} \text { cassettes, respectively }\end{array}$ & This work \\
\hline pCZ750 & pFAJ1700 containing the Kpnl-Ascl-lacZ gene from the pCZ367 plasmid; Tet $^{\mathrm{r}} \mathrm{Amp}^{\mathrm{r}}$ & Dombrecht et al. 2001 \\
\hline pVSSPP & pCZ750 derivative; $\operatorname{dct} P$-lacZ; $\operatorname{Tet}^{\mathrm{r}} \mathrm{Amp}^{\mathrm{r}}$ & This work \\
\hline pSUP202 & ColE1 replicon, mobilizable plasmid, suicide vector suitable for A. brasilense, $\mathrm{Amp}^{\mathrm{r}}, \mathrm{Tet}^{\mathrm{r}}, \mathrm{Cm}^{\mathrm{r}}$ & Simon et al. 1983 \\
\hline pUC4K & Vector containing $\mathrm{Km}^{\mathrm{r}}$ cassette & GE Healthcare \\
\hline pDCTPDVSS & $\operatorname{dctP}(\mathrm{AZOBR}$ 140140) gene disruption plasmid & This work \\
\hline pDCTADVSS & $\operatorname{dct} A$ (AZOBR_p1140111) gene disruption plasmid & This work \\
\hline pMMB 206 & $\mathrm{Cm}^{\mathrm{r}}$, broad host range, low copy number, expression vector & Morales et al. 1991 \\
\hline pDCTPOVSS & $\begin{array}{l}d c t P \text { and its downstream genes, } d c t Q \text { and } d c t M(d c t P Q M \text { operon, 3,124 bp) from A. brasilense } \\
\text { Sp7 cloned into EcoRI/HindIII restriction site of pMMB } 206\end{array}$ & This work \\
\hline pDCTAOVSS & $\operatorname{dctA}(1,320 \mathrm{bp})$ gene cloned into BamHI/HindIII restriction site of pMMB 206 & This work \\
\hline pBBR1MCS-3 & Tet $^{\mathrm{r}}$, broad host range, medium copy number, lac $Z$ gene containing promoter less vector & Kovach el al. 1995 \\
\hline pAKMPVSS & $\begin{array}{l}\text { Constitutive Km promoter and } g f p \text { gene, cloned into } X h o I / X m a I \text { restriction sites of modified } \\
\text { pBBR1MCS-3 vector }\end{array}$ & This work \\
\hline
\end{tabular}

\footnotetext{
${ }^{\mathrm{a}} \mathrm{Sm}^{\mathrm{r}}, \mathrm{Km}^{\mathrm{r}}, \mathrm{Gm}^{\mathrm{r}}, \mathrm{Tet}^{\mathrm{r}}, \mathrm{Amp}^{\mathrm{r}}$, and $\mathrm{Cm}^{\mathrm{r}}=$ streptomycin, kanamycin, gentamycin, tetracycline, ampicillin, and chloramphenicol resistant.
} 


\section{Construction of single and double knockout mutant}

\section{of $\boldsymbol{d c t P}$ and $\boldsymbol{d c t} A$ genes.}

The $d c t P:: k m$ and $d c t A:: g m$ mutants of $A$. brasilense $\mathrm{Sp} 7$ were constructed by inserting gene cassettes encoding resistance to $\mathrm{Km}$ and $\mathrm{Gm}$, respectively, in $\operatorname{dctP}$ (AZOBR_140140) and $\operatorname{dct} A$ (AZOBR_p1140111) genes in vitro, resulting in $d c t P$ - and $d c t A$ disruptive plasmids pDCTPDVSS and pDCTADVSS, respectively. The two recombinant plasmids were then transformed into $E$. coli S17-1 and were conjugatively mobilized in A. brasilense Sp7 (Singh et al. 2017). The exconjugants were selected on LB plates containing $\mathrm{Km}$ and $\mathrm{Gm}$, respectively. The $\operatorname{dctP}:: \mathrm{km}$ and $\operatorname{dctA}:: \mathrm{gm}$ mutants were confirmed by observing expected increase in the size of the amplicons after PCR amplification of respective genes with gene-specific primers (GSPF/R and GSAF/R). Primers used for $d c t P$ and $d c t A$ knockout construction are listed in Table 2 and the recombinant plasmids constructed are listed in Table 1 . For the construction of a $d c t P:: \mathrm{km}$ and $d c t A:: \mathrm{gm}$ double mutant, the $d c t A$ disruptive plasmid (pDCTADVSS) was conjugatively mobilized in the $\operatorname{dctP}:: \mathrm{km}$ mutant of $A$. brasilense $\mathrm{Sp} 7$ and the resulting exconjugants were selected on a LB plate containing both $\mathrm{Km}$ and $\mathrm{Gm}$.

\section{Cloning in broad host range expression vector for complementation.}

The $\operatorname{dctP} Q M$ operon $(3,124 \mathrm{bp})$ and $\operatorname{dct} A(1,320 \mathrm{bp})$ genes were cloned individually in the pMMB206 expression vector (Morales et al. 1991). The resulting recombinant plasmids (pDCTPOVSS and pDCTAOVSS) were conjugatively mobilized in $\operatorname{dct} P:: \mathrm{km}$ and $\operatorname{dctA}:: \mathrm{gm}$, respectively, to evaluate their ability to complement the respective mutants.

\section{Acetylene reduction assay.}

Acetylene reduction assay was performed as described earlier (Tripathi et al. 2002). Briefly, overnight-grown cultures of A. brasilense $\mathrm{Sp} 7$ and its mutants (single and double knockout mutants of $\operatorname{dct} P$ and $\operatorname{dct} A$ genes) grown in $\mathrm{MM}$ containing $40 \mathrm{mM}$ fructose, $10 \mathrm{mM} \mathrm{NH} \mathrm{N}_{4} \mathrm{Cl}$, and appropriate antibiotics were reinoculated in the same medium for growth at $30^{\circ} \mathrm{C}$ with shaking at $180 \mathrm{rpm}$. Cultures of $A$. brasilense $\mathrm{Sp} 7$ and its mutants were harvested from their midlog phase and were washed twice with nitrogen-free medium. Equal numbers of cells of A. brasilense $\mathrm{Sp} 7$ and its mutants was resuspended in $11 \mathrm{ml}$ of nitrogen-free semisolid minimal malate medium to make 0.2 $\mathrm{OD}_{600}$ (Chowdhury et al. 2007) in $22 \mathrm{ml}$ crimp cap headspace vials (Agilent), which were closed tightly (to make air-tight) with crimper. Sealed tubes were incubated for $24 \mathrm{~h}$ at $30^{\circ} \mathrm{C}$ for the development of the pellicle. After pellicle formation, $10 \%$ air (vol/vol) from tubes was replaced with acetylene gas, and tubes were further incubated at $30^{\circ} \mathrm{C}$ for another $24 \mathrm{~h}$. Thereafter, the amount of acetylene gas reduced to ethylene was measured using a gas chromatograph (Agilent Technologies 7890 B GC system) equipped with a flame ionization detector and Agilent J\&W GC column CP-AI203/KCl.

\section{Cell aggregation studies.}

Azospirillum brasilense $\mathrm{Sp} 7$ and its mutants were grown overnight in $\mathrm{MM}$ containing $10 \mathrm{mM} \mathrm{NH}_{4} \mathrm{Cl}$ and equal numbers of cells were harvested by centrifugation for $10 \mathrm{~min}$ at $12,000 \mathrm{rpm}$. The cell pellets were washed twice with nitrogenfree $\mathrm{MM}$ and were reinoculated in fresh minimal malate medium amended with $4 \mathrm{mM} \mathrm{NH} \mathrm{NCl}_{4}$ (Burdman et al. 1998). Cultures were grown with shaking at $150 \mathrm{rpm}$ for $24 \mathrm{~h}$ at $30^{\circ} \mathrm{C}$. Quantification of cell aggregation was done as described earlier (Madi and Henis 1989). Liquid cultures containing the aggregates were transferred to $50-\mathrm{ml}$ test tubes and were allowed to stand for $30 \mathrm{~min}$. Once the complete aggregate got settled and the suspension consisted of free cells, turbidity of each suspension (ODs) was measured at $540 \mathrm{~nm}$ (Genesys spectrophotometer).
The aggregate was then dispersed by sonication for $1 \mathrm{~min}$, and total turbidity was measured at $540 \mathrm{~nm}(\mathrm{ODt})$. The percentage of cell aggregation was quantified as follows: $\%$ aggregation $=\mathrm{ODt}-$ ODs $\times 100 \div$ ODt.

GFP-tagging, inoculation, seedling growth conditions, confocal microscopy, and measurement of root growth.

A. brasilense $\mathrm{Sp} 7$ and its mutants were genetically tagged with the GFP reporter. The vector pBBR1MCS-3 (Kovach et al. 1995) was modified by introducing a gene encoding GFP under the control of a constitutively expressed $\mathrm{Km}$ promoter to obtain the recombinant plasmid pAKMPVSS (unpublished), which was conjugatively mobilized into A. brasilense $\mathrm{Sp} 7$ and its three mutants via $E$. coli $\mathrm{S} 17-1$ in separate matings. Exconjugants showing green fluorescence under UV illumination were selected for further study. Seeds of finger millet (Eleusine coracana) were surface-sterilized with $0.1 \%$ mercuric chloride $\left(\mathrm{HgCl}_{2}\right)$ for $1 \mathrm{~min}$ followed by washing six times with sterile distilled water. The seeds were then immersed in $2 \%$ (wt/vol) sodium hypochlorite for $30 \mathrm{~min}$ in an incubator shaker. Finally, the seeds were washed with sterile water (five or six times) with shaking and were incubated on Whatman filter paper wetted with Hoagland's solution at $30^{\circ} \mathrm{C}$ for 3 days, for germination. Seedlings were washed with sterile water and were transferred to a $75-\mathrm{ml}$ cotton plug-tightened test tube containing $25 \mathrm{ml}$ of Hoagland's solution (Hoagland and Arnon 1950) and paper brick. Seedling were allowed to grow further on paper brick submerged in Hoagland's solution in a plant growth chamber with a 15-h light and 9-h dark regimen for 5 days. The $g f p$ tagged $A$. brasilense $\mathrm{Sp} 7$, its three mutants, and an untagged A. brasilense were grown in $\mathrm{MM}$ with fructose $(40 \mathrm{mM})$ as carbon source. One milliliter of bacterial cultures containing a total of $10^{5}$ cells were pelleted, washed, and inoculated, in each tube, in Hoagland's solution after 5 days of seedling growth. One set of the seedlings was further cultivated for 10 more days in a controlled plant growth chamber at $24^{\circ} \mathrm{C}$ with a 15 -h light and 9-h dark regimen. After 10 days, the roots of finger millet inoculated with $g f p$-tagged $A$. brasilense and its $\mathrm{C}_{4}$-dicarboxylate transporter mutants were gently washed with deionized water. The microscopic observation was performed under confocal microscope (LSM 880, Carl Zeiss) with 10 and 40x Plan-Apochromat lenses using $\lambda$ ex-488 $\mathrm{nm}$ and $\lambda \mathrm{em}-590$ to $553 \mathrm{~nm}$. Images were collected in z-series with a step size of $1.0 \mu \mathrm{m}$ and were processed with ZEN software (Carl Zeiss). The effect of inoculation of $A$. brasilense $\mathrm{Sp} 7$ and its three mutants on the root morphology of seedlings was monitored in 10 tubes, each containing three seedlings for each bacterial treatment. Seedlings were allowed to grow for 20 days postbacterial inoculation and were taken out for photography of the root morphology and measurement of the length of the primary root and the number of secondary roots.

\section{Statistical analysis.}

Experiments on measurement of growth, $\beta$-galactosidase activity, flocculation, and acetylene reduction assay were performed in triplicates in three independent experiments. The mean significant values were determined by using SPSS 17 package software. Analysis of variance followed by Duncan's multiple comparison test was used to analyze significance between more than two treatments. Differences were considered significant at $P<0.05$.

\section{LITERATURE CITED}

Agarwala, R., and Tilak, K. V. B. R. 1988. Establishment of Azospirillum brasilense in roots of finger millet (Eleusine coracana). Zentralbl. Mikrobiol. 143:539-544. 
Albrecht, S. L., and Okon, Y. 1980. Pages 739-749 in: Culture of Azospirillum. Methods in Enzymology, Vol. 69. A. San Pietro, ed. Academic Press, New York.

Alexandre, G., Greer, S. E., and Zhulin, I. B. 2000. Energy taxis is the dominant behavior in Azospirillum brasilense. J. Bacteriol. 182: 6042-6048.

Asai, K., Baik, S. H., Kasahara, Y., Moriya, S., and Ogasawara, N. 2000. Regulation of the transport system for $\mathrm{C}_{4}$-dicarboxylic acids in Bacillus subtilis. Microbiology 146:263-271.

Barak, R., Nur, I., and Okon, Y. 1983. Detection of chemotaxis in Azospirillum hrasilense. J. Appl. Bacteriol. 54:399-403.

Bardgett, R. D., Mommer, L., and De Vries, F. T. 2014. Going underground: Root traits as drivers of ecosystem processes. Trends Ecol. Evol. Amst. 29:692-699.

Bashan, Y., and Levanony, H. 1989. Factors affecting adsorption of Azospirillum brasilense $\mathrm{Cd}$ to root hairs as compared with root surface of wheat. Can. J. Microbiol. 35:936-944.

Bible, A., Russell, M. H., and Alexandre, G. 2012. The Azospirillum brasilense Che 1 chemotaxis pathway controls swimming velocity, which affects transient cell-to-cell clumping. J. Bacteriol. 194:3343-3355.

Bradford, M. M. 1976. A rapid and sensitive method for the quantitation of microgram quantities of protein utilizing the principle of protein-dye binding. Anal. Biochem. 72:248-254.

Burdman, S., Jurkevitch, E., Schwartsburd, B., Hampel, M., and Okon, Y. 1998. Aggregation in Azospirillum brasilense: Effects of chemical and physical factors and involvement of extracellular components. Microbiology 144:1989-1999.

Chowdhury, S. P., Nagarajan, T., Tripathi, R., Mishra, M. N., Le Rudulier, D.Le., and Tripathi, A. K. 2007. Strain-specific salt tolerance and osmoregulatory mechanisms in Azospirillum brasilense. FEMS Microbiol. Lett. 267:72-79.

Christiansen-Weniger, C. 1992. $\mathrm{N}_{2}$-fixation by ammonium-excreting Azospirillum brasilense in auxin-induced root tumours of wheat (Triticum aestivum L.). Biol. Fertil. Soils 13:165-172.

Coskun, D., Britto, D. T., Shi, W., and Kronzucker, H. J. 2017. How plant root exudates shape the nitrogen cycle. Trends Plant Sci. 22:661-673.

Davies, S. J., Golby, P., Omrani, D., Broad, S. A., Harrington, V. L., Guest, J. R., Kelly, D. J., and Andrews, S. C. 1999. Inactivation and regulation of the aerobic C(4)-dicarboxylate transport (dctA) gene of Escherichia coli. J. Bacteriol. 181:5624-5635.

Dombrecht, B., Vanderleyden, J., and Michiels, J. 2001. Stable RK2derived cloning vectors for the analysis of gene expression and gene function in gram-negative bacteria. Mol. Plant-Microbe Interact 14: 426-430.

Driscoll, B. T., and Finan, T. M. 1993. NAD ${ }^{+}$-dependent malic enzyme of Rhizobium meliloti is required for symbiotic nitrogen fixation. Mol. Microbiol. 7:865-873.

Engelke, T., Jagadish, M. N., and Puhler, A. 1987. Biochemical and genetical analysis of Rhizobium meliloti mutants defective in $\mathrm{C}_{4}$ dicarboxylate transport. J. Gen. Microbiol. 133:3019-3029.

Engelke, T., Jording, D., Kapp, D., and Pühler, A. 1989. Identification and sequence analysis of the Rhizobium meliloti $d c t A$ gene encoding the $\mathrm{C}_{4}$-dicarboxylate carrier. J. Bacteriol. 171:5551-5560.

Finan, T. M., Oresnik, I., and Bottacin, A. 1988. Mutants of Rhizobium meliloti defective in succinate metabolism. J. Bacteriol. 170:3396-3403.

Forward, J. A., Behrendt, M. C., Wyborn, N. R., Cross, R., and Kelly, D. J. 1997. TRAP transporters: A new family of periplasmic solute transport systems encoded by the $d c t P Q M$ genes of Rhodobacter capsulatus and by homologs in diverse gram-negative bacteria. J. Bacteriol. 179: 5482-5493.

Goebel, E. M., and Krieg, N. R. 1984. Fructose catabolism in Azospirillum brasilense and Azospirillum lipoferum. J. Bacteriol. 159:86-92.

Hamblin, M. J., Shaw, J. G., and Kelly, D. J. 1993. Sequence analysis and interposon mutagenesis of a sensor-kinase (DctS) and response-regulator (DctR) controlling synthesis of the high-affinity $\mathrm{C}_{4}$-dicarboxylate transport system in Rhodobacter capsulatus. Mol. Gen. Genet. 237: 215-224.

Hardarson, G., and Hera, C. 1998 . Use of $15^{\mathrm{N}}$ isotope dilution method to quantify nitrogen fixation in legumes and its potential use for nonlegumes. Pages 307-312 in: Nitrogen Fixation with Non-Legumes, K. A. Malik, M. S. Mirza, and J. K. Ladha, eds. Springer, Dortrecht, The Netherlands.

Heinrich, D., and Hess, D. 1985. Chemotactic attraction of Azospirillum lipoferum by wheat roots and characterization of some attractants. Can. J. Microbiol. 31:26-31.

Hoagland, D. R., and Arnon, D. I. 1950. The water-culture method for growing plants without soil. University of California, College of Agriculture, Agricultural Experiment Station, Berkeley, Calif.
Janausch, I. G., Zientz, E., Tran, Q. H., Kröger, A., and Unden, G. 2002. C $4^{-}$ dicarboxylate carriers and sensors in bacteria. Biochim. Biophys. Acta 1553:39-56.

Jones, D. T., Taylor, W. R., and Thornton, J. M. 1992. The rapid generation of mutation data matrices from protein sequences. Comput. Appl. Biosci. 8:275-282.

Jording, D., Uhde, C., Schmidt, R., and Puhler, A. 1994. The $\mathrm{C}_{4^{-}}$ dicarboxylate transport system of Rhizobium meliloti and its role in nitrogen fixation during symbiosis with Alfalfa (Medicago sativa). Experientia 50:874-883.

Kovach, M.E., Elzer, P. H., Hill, D. S., Robertson, G.T., Farris, M. A., Roop, R. M., Peterson, K. M. 1995. Four new derivatives of the broad-hostrange cloning vector pBBR1MCS, carrying different antibioticresistance cassettes. Gene 1:175-176.

Madi, L., and Henis, Y. 1989. Aggregation in Azospirillum brasilense Cd: Conditions and factors involved in cell-to-cell adhesion. Plant Soil 115: 89-98.

Mandimba, G., Heulin, T., Bally, R., Guckert, A., and Balandreau, J. 1986. Chemotaxis of free-living nitrogen-fixing bacteria towards maize mucilage. Plant Soil 90:129-139.

Martinez-Drets, G., Del Gallo, M., Burpee, C., and Burris, R. H. 1984. Catabolism of carbohydrates and organic acids and expression of nitrogenase by azospirilla. J. Bacteriol. 159:80-85.

Michiels, K. W., Croes, C. L., and Vanderleyden, J. 1991. Two different modes of attachment of Azospirillum brasilense $\mathrm{Sp} 7$ to wheat roots. J. Gen. Microbiol. 137:2241-2246.

Miller, J. H. 1972. Experiments in Molecular Genetics. Cold Spring Harbor Laboratory Press, Cold Spring Harbor, NY, U.S.A.

Mishra, M. N., Kumar, S., Gupta, N., Kaur, S., Gupta, A., and Tripathi, A. K. 2011. An extracytoplasmic function sigma factor cotranscribed with its cognate anti-sigma factor confers tolerance to $\mathrm{NaCl}$, ethanol and methylene blue in Azospirillum brasilense Sp7. Microbiology 157: 988-999.

Mora-Macías, J., Ojeda-Rivera, J. O., Gutiérrez-Alanís, D., Yong-Villalobos, L., Oropeza-Aburto, A., Raya-González, J., Jiménez-Domínguez, G., Chávez-Calvillo, G., Rellán-Álvarez, R., and Herrera-Estrella, L. 2017. Malate-dependent $\mathrm{Fe}$ accumulation is a critical checkpoint in the root developmental response to low phosphate. Proc. Natl. Acad. Sci. U.S.A. 114:E3563-E3572.

Morales, V. M., Bäckman, A., and Bagdasarian, M. 1991. A series of widehost-range low-copy-number vectors that allow direct screening for recombinants. Gene 97:39-47.

Mukherjee, A., and Ghosh, S. 1987. Regulation of fructose uptake and catabolism by succinate in Azospirillum brasilense. J. Bacteriol. 169: 4361-4367.

Mulligan, C., Fischer, M., and Thomas, G. H. 2011. Tripartite ATPindependent periplasmic (TRAP) transporters in bacteria and archaea. FEMS Microbiol. Rev. 35:68-86.

Neyra, C. A., and Döbereiner, J. 1977. Nitrogen fixation in grasses. Adv. Agron. 29:1-38.

Nur, I., Steinitz, Y. L., Okon, Y., and Henis, Y. 1981. Carotenoid composition and function in nitrogen-fixing bacteria of the genus Azospirillum. J. Gen. Microbiol. 122:27-32.

Okon, Y., Albrecht, S. L., and Burris, R. H. 1976. Factors affecting growth and nitrogen fixation of Spirillum lipoferum. J. Bacteriol. 127: 1248-1254.

Okon, Y., Cakmakci, L., Nur, I., and Chet, I. 1980. Aerotaxis and chemotaxis of Azospirillum brasilense: A note. Microb. Ecol. 6:277-280.

Okon, Y., and Kapulnik, Y. 1986. Development and function of Azospirillum inocuiated roots. Plant Soil 90:3-16.

Pereg, L., de-Bashan, L. E., and Bashan, Y. 2016. Assessment of affinity and specificity of Azospirillum for plants. Plant Soil 399:389-414.

Pereg-Gerk, L., Paquelin, A., Gounon, P., Kennedy, I. R., and Elmerich, C. 1998. A transcriptional regulator of the LuxR-UhpA family, FlcA, controls flocculation and wheat root surface colonization by Azospirillum brasilense Sp7. Mol. Plant-Microbe Interact 11:177-187.

Rai, R. 1991. Strain-specific salt tolerance and chemotaxis of Azospirillum brasilense and their associative $\mathrm{N}$-fixation with finger millet in saline calcareous soil. Plant Soil 137:55-59.

Ramos, H. J., Roncato-Maccari, L. D., Souza, E. M., Soares-Ramos, J. R., Hungria, M., and Pedrosa, F. O. 2002. Monitoring Azospirillum-wheat interactions using the $g f p$ and $g u s A$ genes constitutively expressed from a new broad-host range vector. J. Biotechnol. 97:243-252.

Reid, C. J., and Poole, P. S. 1998. Roles of DctA and DctB in signal detection by the dicarboxylic acid transport system of Rhizobium leguminosarum. J. Bacteriol. 180:2660-2669.

Reinhold, B., Hurek, T., and Fendrik, I. 1985. Strain-specific chemotaxis of Azospirillum spp. J. Bacteriol. 162:190-195. 
Ronson, C. W., Astwood, P. M., and Downie, J. A. 1984. Molecular cloning and genetic organization of $\mathrm{C}_{4}$-dicarboxylate transport genes from Rhizobium leguminosarum. J. Bacteriol. 160:903-909.

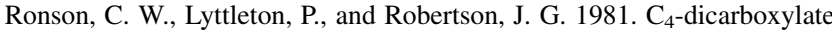
transport mutants of Rhizobium trifolii form ineffective nodules on Trifolium repens. Proc. Natl. Acad. Sci. U.S.A. 78:4284-4288.

Rudrappa, T., Czymmek, K. J., Paré, P. W., and Bais, H. P. 2008. Rootsecreted malic acid recruits beneficial soil bacteria. Plant Physiol. 148: 1547-1556.

Sadasivan, L., and Neyra, C. A. 1985. Flocculation in Azospirillum brasilense and Azospirillum lipoferum: Exopolysaccharides and cyst formation. J. Bacteriol. 163:716-323.

Schank, S. C., Smith, R. L., Weiser, G. C., Zuberer, D. A., and Bouton, J. H. 1979. Fluorescent antibody technique to identify Azospirillum brasilense associated with roots of grasses. Soil Biol. Biochem. 11:287-295.

Shaw, J. G., and Kelly, D. J. 1991. Binding protein dependent transport of $\mathrm{C}_{4}$-dicarboxylates in Rhodobacter capsulatus. Arch. Microbiol. 155: 466-472.

Simon, R., Priefer, U., and Puehler, A. 1983. A broad host range mobilization system for in vivo genetic engineering: Transposon mutagenesis in gram negative bacteria. Nat. Biotechnology 1:784-791.

Singh, V. S., Dubey, A. P., Gupta, A., Singh, S., Singh, B. N., and Tripathi, A. K. 2017. Regulation of a glycerol induced quinoprotein alcohol dehydrogenase by $\sigma 54$ and a LuxR-type regulator in Azospirillum brasilense Sp7. J. Bacteriol. 199:e00035-17.

Steenhoudt, O., and Vanderleyden, J. 2000. Azospirillum, a free-living nitrogen-fixing bacterium closely associated with grasses: Genetic, biochemical and ecological aspects. FEMS Microbiol. Rev. 24:487-506.

Subba Rao, N. S. 1985. Effect of combined inoculation of Azospirillum brasilense and vesicular arbuscular mycorrhiza on pearl millet (Pennisetum americanum). Plant Soil 81:283-286.

Teramoto, H., Shirai, T., Inui, M., and Yukawa, H. 2008. Identification of a gene encoding a transporter essential for utilization of $\mathrm{C} 4$ dicarboxylates in Corynebacterium glutamicum. Appl. Environ. Microbiol. 74: 5290-5296.

Tilak, K. V. B. R., and Subba Rao, N. S. 1987. Association of Azospirillum brasilense with pearl millet (Pennisetum americanum). Biol. Fertil. Soils 4:97-102.

Trautwein, K., Lahme, S., Wöhlbrand, L., Feenders, C., Mangelsdorf, K., Harder, J., Steinbüchel, A., Blasius, B., Reinhardt, R., and Rabus, R. 2012. Physiological and proteomic adaptation of "Aromatoleum aromaticum" EbN1 to low growth rates in benzoate-limited, anoxic chemostats. J. Bacteriol. 194:2165-2180.

Tripathi, A. K., Nagarajan, T., Verma, S. C., and Rudulier, D. L. 2002. Inhibition of biosynthesis and activity of nitrogenase in Azospirillum brasilense Sp7 under salinity stress. Curr. Microbiol. 44:363-367.

Umali-Garcia, M., Hubbell, D. H., Gaskins, M. H., and Dazzo, F. B. 1980. Association of Azospirillum with grass roots. Appl. Environ. Microbiol. 39:219-226.
Valentini, M., Storelli, N., and Lapouge, K. 2011. Identification of $\mathrm{C}_{4}$ dicarboxylate transport systems in Pseudomonas aeruginosa PAO1. J. Bacteriol. 193:4307-4316.

Van de Broek, A., Lambrecht, M., and Vanderleyden, J. 1998. Bacterial chemotactic motility is important for the initiation of wheat roo colonization by Azospirillum brasilense. Microbiology 144:2599-2606.

Vande Broek, A., Michiels, J., Van Cool, A., and Vanderleyden, J. 1993. Spatial-temporal colonization patterns of Azospirillum brasilense on the wheat root surface and expression of the bacterial nifH gene during association. Mol Plant-Microbe lnteract. 6:592-600.

Vanstockem, M., Michiels, K., Vanderleyden, J., and Van Gool, A. P. 1987. Transposon mutagenesis of Azospirillum brasilense and Azospirillum lipoferum, physical analysis of Tn5 and Tn5-mob insertion mutants. Appl. Environ. Microbiol. 53:410-415.

Vetting, M. W., Al-Obaidi, N., Zhao, S., San Francisco, B., Kim, J., Wichelecki, D. J., Bouvier, J. T., Solbiati, J. O., Vu, H., Zhang, X., Rodionov, D. A., Love, J. D., Hillerich, B. S., Seidel, R. D., Quinn, R. J., Osterman, A. L., Cronan, J. E., Jacobson, M. P., Gerlt, J. A., and Almo, S. C. 2015. Experimental strategies for functional annotation and metabolism discovery: Targeted screening of solute binding proteins and unbiased panning of metabolomes. Biochemistry 54:909-931.

Vranova, V., Rejsek, K., Skene, K. R., Janous, D., and Formanek, P. 2013. Methods of collection of plant root exudates in relation to plant metabolism and purpose: A review. J. Plant Nutr. Soil Sci. 176: 175-199.

Wani, S. P., Chandrapalaiah, S., and Dart, P. J. 1985. Response of pearl millet cultivars to inoculation with nitrogen-fixing bacteria. Exp. Agric. 21:175-182.

Watson, R. J., Chan, Y. K., Wheatcroft, R., Yang, A. F., and Han, S. H. 1988 Rhizobium meliloti genes required for $\mathrm{C}_{4}$-dicarboxylate transport and symbiotic nitrogen fixation are located on a megaplasmid. J. Bacteriol. 170:927-934.

Youn, J. W., Jolkver, E., Krämer, R., Marin, K., and Wendisch, V. F. 2009. Characterization of the dicarboxylate transporter DctA in Corynebacterium glutamicum. J. Bacteriol. 191:5480-5488.

Yurgel, S. N., and Kahn, M. L. 2004. Dicarboxylate transport by rhizobia. FEMS Microbiol. Rev. 28:489-501.

Yurgel, S. N., and Kahn, M. L. 2005. Sinorhizobium meliloti dctA mutants with partial ability to transport dicarboxylic acids. J. Bacteriol. 187: 1161-1172.

\section{AUTHOR-RECOMMENDED INTERNET RESOURCES}

European Bioinformatics Institute ClustalW multiple sequence alignment tool: https://www.ebi.ac.uk/Tools/msa/clustalw2

Genoscope Acinetobacter baylyi ADP1 map: https://www.genoscope.cns.fr/agc/microscope/mage/viewer.php

National Center for Biotechnology Information website: https://www.ncbi.nlm.nih.gov 